\title{
Domestic Political Survival and International Conflict: Is Democracy Good for Peace?*
}

\author{
Sandeep Baliga \\ David O. Lucca \\ Kellogg School of Management, \\ Federal Reserve Board \\ Northwestern University \\ Tomas Sjöström \\ Department of Economics, \\ Rutgers University \\ This Version: July 2009
}

\begin{abstract}
We build a game-theoretic model where aggression can be triggered by domestic political concerns as well as the fear of being attacked. In the model, leaders of full and limited democracies risk losing power if they do not stand up to threats from abroad. In addition, the leader of a fully democratic country loses the support of the median voter if he attacks a non-hostile country. The result is a non-monotonic relationship between democracy and peace. Using the Polity IV dataset, we classify countries as full democracies, limited democracies, and dictatorships. For the period 1816-2000, Correlates of War data suggest that limited democracies are more aggressive than other regime types, including dictatorships, and not only during periods when the political regime is changing. In particular, a dyad of limited democracies is more likely to be involved in a militarized dispute than any other dyad (including "mixed" dyads, where the two countries have different regime types). Thus, while full democratization might advance the cause of peace, limited democratization might advance the cause of war. We also find that as the environment becomes more hostile, fully democratic countries become more aggressive faster than other regime types.
\end{abstract}

\footnotetext{
${ }^{*}$ We thank the Editor and three referees for many suggestions that improved the paper. We also thank Igal Hendel, Massimo Morelli, Gerard Padro-i-Miguel, Ben Polak, Bruce Russett, Paola Sapienza and Francesco Trebbi, and many seminar participants. The views and analysis in this paper are solely those of the authors and do not indicate concurrence by other members of the Federal Reserve System.
} 


\section{Introduction}

The idea that democracy promotes peace has a long history. Thomas Paine argued that monarchs go to war to enrich themselves, but a more democratic system of government would lead to lasting peace: "What inducement has the farmer, while following the plough, to lay aside his peaceful pursuit, and go to war with the farmer of another country?" (Paine [57] p. 169). Immanuel Kant [45] agreed: "if the consent of the citizens is required in order to decide that war should be declared, nothing is more natural than that they would be very cautious in commencing such a poor game." More recently, the democratic peace hypothesis has influenced the "neoconservative" view of international relations (Kaplan and Kristol [44]). U.S. policy makers of different political persuasions have invoked it in support of a policy to "seek and support the growth of democratic movements and institutions in every nation and culture." ${ }^{1}$ But some anecdotal observations seem to support a more "realist" viewpoint. ${ }^{2}$ For example, after the breakup of Yugoslavia, democratic reforms were followed by war, not peace. When given a chance in the legislative elections of 2006, the Palestinians voted for Hamas, which did not have a particularly peaceful platform. Such anecdotes suggest that democratization does not always promote peace. Even fully democratic countries such as the U.S. sometimes turn aggressive: under perceived threats to the homeland, the democratically elected President George W. Bush declared war on Iraq.

We develop a simple game-theoretic model of conflict, based on Baliga and Sjöström [6]. Each leader can behave aggressively or peacefully. A leader's true propensity to be aggressive, his "type", is his private information. Since actions are strategic complements, the fear that the other leader might be an aggressive type can trigger aggression, creating a fear-spiral we call "Schelling's dilemma" (see Schelling [63], Jervis [41], [42] and Kydd [46]). Unlike Baliga and Sjöström [6], we assume a leader may be removed from power. Whether a leader can stay in power depends on the preferences of his citizens, the political system, and the outcome of the interaction between the two countries. The political system interacts with Schelling's dilemma to create a non-monotonic relationship between democracy and peace.

Like the leaders, citizens have different types. By hypothesis, the median type prefers to live in peace. This imposes a "dovish bias" on a dyad of two full democracies (whose leaders can be replaced by their median voters). Thus, a dyadic democratic peace is likely to obtain. However, if the other country is not fully democratic, then the median voter may support aggression out of fear, and may replace a leader who is not aggressive enough. (For example, Neville Chamberlain had to resign after appeasing Hitler.) This gives rise to a "hawkish bias". Thus, in a fully democratic

\footnotetext{
${ }^{1}$ President George W. Bush's second inaugural address. Similarly, President Clinton noted that "the best strategy to ensure our security and to build a durable peace is to support the advance of democracy elsewhere. Democracies do not attack each other." (1994 State of the Union address).

${ }^{2}$ For a realist view, see Scowcroft [34]:
}

"I don't think in any reasonable time frame the objective of democratizing the Middle East can be successful. If you can do it, fine, but I don't think you can, and in the process of trying to do it, you can make the Middle East a lot worse." 
country, a dovish bias is replaced by a hawkish bias when the environment becomes more hostile. In contrast, a dictator is not responsive to the preferences of his citizens, so there is neither a hawkish nor a dovish bias. Accordingly, a dyad of two dictators is less peaceful than a fully democratic dyad, but a dictator responds less aggressively than a democratically elected leader to increased threats from abroad.

In the model, the leader of a limited democracy risks losing power if hawks in his population turn against him. For instance, the German leaders during World War I believed signing a peace agreement would lead to their demise (Asprey [3], p. 486-487, and p. 491). Conversely, the support of the hawkish minority trumps the opposition of more peaceful citizens. Thus, a limited democracy experiences a hawkish bias similar to a full democracy under threat from abroad, but never a dovish bias. On balance, this makes limited democracies more aggressive than any other regime type. In a full democracy, if the citizens feel safe they want a dovish leader, but if they feel threatened they want a hawkish leader. In dictatorships and limited democracies, the citizens are not powerful enough to overthrow a hawkish leader, but the leader of a limited democracy risks losing power if he cannot appease a hawkish constituency. This generates a non-monotonic relationship between democracy and peace.

Our empirical analysis reassesses the link between democracy and peace using a flexible semiparametric functional form, where fixed effects account for unobserved heterogeneity across dyads. We use Polity data to classify regimes as dictatorships, limited democracies or full democracies. Following the literature on the democratic peace hypothesis, we define a conflict as a militarized dispute in the Correlates of War data set. The data, which spans over the period 1816-2000, contain many military disputes between limited democracies. In the nineteenth century, Britain has a Parliament, but even after the Great Reform Act of 1832, only about 200,000 people are allowed to vote. Those who own property in multiple constituencies can vote multiple times. ${ }^{3}$ Hence, Britain is classified as a limited democracy for 58 years, and becomes a full democracy only after 1879. France, Italy, Spain and Germany are also limited democracies at key points in the nineteenth and early twentieth centuries. These countries, together with Russia and the Ottoman Empire, are involved in many militarized disputes in Europe and throughout the world. For much of the nineteenth century, Britain and Russia have many skirmishes and outright wars in the "Great Game" for domination of Central Asia (Hopkirk [38]). France is also involved in many disputes and is a limited democracy during the Belgian War of Independence and the Franco-Prussian War. Germany is a limited democracy at the start of the First World War.

Over the full sample, spanning 1816- 2000, the data strongly supports a dyadic democratic peace hypothesis: dyads consisting of two full democracies are more peaceful than all other pairs of regime types. This is consistent with previous empirical studies (Babst [5], Levy [49], Maoz and Russett [53] and Russett and Oneal [62]). Over the same period, limited democracies were the most aggressive regime type. In particular, dyads consisting of two limited democracies are more

\footnotetext{
${ }^{3}$ The infamous "rotten borough" of Old Sarum sent two representatives to Parliament. In 1831, it had only eleven eligible voters, all of whom were landowners living elsewhere (Paine [57]).
} 
likely to experience militarized disputes than any other dyads, including "mixed" dyads where the two countries have different regime types. These results are robust to changing the definitions of the three categories (using the Polity scores), and to alternative specifications of our empirical model. The effects are quantitatively significant. Parameter estimates of a linear probability model specification, for example, suggest that the likelihood that a dyad engages in a militarized dispute falls roughly 35 percent if the dyad changes from a pair of limited democracies to a pair of dictatorships. We also find that if some country $j$ faces an opponent which changes from a full democracy to another regime type, the estimated equilibrium probability of conflict increases most dramatically when country $j$ is a full democracy. This suggests that as the environment becomes more hostile, democracies respond more aggressively than other regime types, which is also consistent with our theoretical model.

A more nuanced picture emerges when we split the data into sub-samples. Before World War II, the data strongly suggest that limited democracies were the most conflict-prone. It is harder to draw conclusions for the post World War II period, when very few countries are classified as limited democracies, and full democracies have very stable Polity scores. The Cold War was a special period where great power wars became almost unthinkable due to the existence of large nuclear arsenals (Gaddis [32]). Did the weakening and demise of the Soviet Union bring a return to the pre-1945 patterns? Although the time period is arguably short, in the post-1984 period it does seem that dyads of limited democracies are again the most prone to conflict.

It is commonly argued that a process of democratization, for example in the Middle East, will lead to peace (George W. Bush [16]). But both theory and data suggest that the relationship between democracy and peace may be complex and non-monotonic. Replacing a dictatorship with a limited democracy may actually increase the risk of militarized disputes. Even if a dictatorship is replaced by a full democracy, this may not reduce the risk of militarized disputes if the region is dominated by hostile non-democratic countries. In the data, only dyads consisting of two full democracies are peaceful. Democratic countries such as Israel and India, with hostile neighbors, do not enjoy a low level of conflict.

The paper is organized as follows. Related literature is discussed in the next section. The theoretical model is presented in Section 3. Section 4 describes the empirical results. Section 5 concludes.

\section{Related Literature}

Theoretical and empirical work in economics and political science has investigated the relationship between political systems and interstate and civil war. Jackson and Morelli [40] formalize the idea that leaders start wars when their preferences are sufficiently biased away from their citizens' preferences. Levy and Razin [50] provide a theory of the democratic peace based on incomplete information. They assume the representative citizen is less well informed about the benefit of concessions than the leader, and show that democratically elected leaders are more likely to reveal 
information truthfully. In the model of Bueno de Mesquita et. al. [13], political leaders must bribe key supporters to stay in power when foreign policy fails. A dictator has to bribe fewer supporters and is therefore more likely to go to war than a democratically elected leader. On the other hand, in order to avoid being replaced, a leader may "gamble for resurrection" with an aggressive foreign policy (Downs and Rocke [22], Bueno de Mesquita and Silverson [12] and Hess and Orphanides [37]). Fearon [25] assumes leaders suffer "audience costs" if they back down during a war of attrition. If audience costs are higher in democracies, then democracies are more committed to a conflict and may be more reluctant to enter into one. Tangeras [68] assumes leaders have private information about the probability of winning a war. Democratically elected leaders are more reluctant to start a war, because they will lose power if the war ends badly. According to Leeds [47], democratic leaders are more able to commit to honouring agreements, and thus more able to cooperate.

These theories provide underpinnings for the democratic peace hypothesis, but it is not obvious how they can be extended to explain the non-monotonicity we find in the data. For example, a natural extension of Fearon's [25] model would be to introduce limited democracies which have higher audience costs than dictatorships (although not as high as full democracies), but these limited democracies would not be more conflict-prone than dictatorships. Similarly, assuming the leader of a limited democracy has less biased preferences than a dictator, the Jackson and Morelli [40] model would predict that limited democracies go to war less often than dictatorships.

Our theory incorporates an important feature of Bueno de Mesquita et. al. [13]: the support for the leader's action is derived from heterogeneous preferences among the citizens. In our model, leaders of full and limited democracies suffer audience costs (as in Fearon [25]) if they are dovish when the opposing leader is hawkish; in addition, a leader of a full democracy faces audience costs (from the median voter) if he is hawkish against a dovish opponent; a dictator faces no audience costs at all. The result is a non-monotonic relationship between democracy and peace.

Mansfield and Snyder [51] argue that increased nationalism can cause conflict during a period of transition when a regime is being democratized. However, in our baseline empirical model, dyads of limited democracies are the most conflict-ridden even when controlling for regime transitions (using Mansfield and Snyder's [51] transitional dummies). This suggests that limited democracies are not only prone to conflict during periods of transition. Nonetheless, for alternative definitions of regime types, we find support for both our theory and Mansfield and Snyder's [51] hypothesis.

Several articles have investigated the hypothesis that dyads consisting of countries with similar regime types, and thus perhaps "shared values", are relatively peaceful. Peceny, Beer and SanchezTerry [58] classify autocratic regimes as personalist, military and single-party dictatorships, and find evidence that dyads consisting of two autocracies of the same type are relatively peaceful. Bennett [10] analyzes plots of conflict probabilities for dyads with different Polity scores. He finds that the hypothesized relationship between similarity and peace holds for dyads with either very high or very low Polity scores, but not in the intermediate range. This is consistent with our finding that dyads consisting of two limited democracies (which have intermediate Polity scores by definition) are relatively conflict prone. However, it is challenging within Bennett's pooled 
logit specification to formally test non-monotonicity, and to assess robustness within higher-order parametric specifications, because the functional form is bidimensional and marginal effects are nonlinear functions of explanatory variables. In addition, his specification cannot include dyadic fixed effects. Our dummy variable nonparametric approach has dyad-specific fixed effects, and non-monotonicity can be assessed through simple tests on coefficients. Unlike Bennett's continuous specification, we define limited democracies by cut-off Polity scores; but we verify the robustness of our results by varying the cut-off points.

Other authors have analyzed limited democracies along other dimensions, and found reasons for why such regimes might experience conflicts. Fearon and Laitin [28] find that limited democracies are more prone to civil wars, as insurgencies are more likely to succeed in weaker political regimes. Epstein et al. [23] find that political transitions from limited democracies to other political regimes are harder to explain than political transitions of autocracies and full democracies.

Determining the underlying motives behind conflicts, based on a subjective reading of history, will always leave scope for disagreement. Our theoretical model, building on Baliga and Sjöström [6], assumes conflicts can be sparked by fear ("Schelling's dilemma"). Historians have uncovered many examples of such "fear-spirals". For example, Thucydides ([70], 1.23, p. 49) argued that the Peloponnesian War was caused by "the growth of Athenian power and the fear which this caused in Sparta." The period that preceded World War I was characterized by mutual distrust and fear (Tuchman [72], Wainstein [75] and Sontag [67]). A spiral of fear was evident during the Cold War arms race (Leffler [48]). The India-Pakistan arms race is a current example of escalation fueled by mutual distrust, and Bobbitt (p. 10, [11]) suggests a similar logic will continue to operate in the wars of the twenty-first century: "We think terrorists will attack; so they think we think the terrorists will attack; so they think we shall intervene; so they will attack; so we must." Nevertheless, there is disagreement about the number of large-scale wars that can be said to have been triggered by fear (see Reiter [61] and Van Evera [73]). Reiter [60] argues that leaders who understand the spiraling logic can prevent conflict by communicating. Baliga and Sjöström [6] verify that, in theory at least, cheap-talk can sometimes prevent a conflict; but it cannot always do so. Our current model assumes leaders are partly motivated by domestic political concerns, and may behave hawkishly in order to maintain political support. Thus, fear is not the only reason for starting a war, and Reiter's [60] argument that World War I was not a pure fear-spiral is consistent with our model:

"Domestic politics in a number of nations set the stage for war, though some...have gone further to argue that Germany sought war... to shore up the threatened domestic political order at home" (Reiter [60], p. 22)

\section{A Simple Model of Schelling's Dilemma}

\subsection{Basic Assumptions}

There are two countries, $i \in\{1,2\}$. Each country $i$ has a leader, leader $i$, and a continuum of citizens. The two leaders play a game which is similar to the arms race game of Baliga and Sjöström 
[6]. Each leader can choose an aggressive (hawkish) strategy $A$ or a peaceful (dovish) strategy $P$. The aggressive strategy may represent building new weapons, firing a missile, preparing for war, or attacking the other country. Each citizen has a cost type, a cost of aggression $c$, which is drawn from a distribution $F$ with support $[\underline{c}, \bar{c}]$. We assume $F$ is continuous, strictly increasing and concave. The median cost type is denoted $c^{\text {med }}$, so $F\left(c^{\text {med }}\right)=1 / 2$. Each leader $i$ has a cost type $c_{i}$ which is independently drawn from the same distribution $F$. Each leader's type is his private information. Everything else is common knowledge. To study the pure impact of political institutions on the incentive to go to war, we assume there is no ex ante difference between the two countries: the distribution $F$ is the same in both.

The payoff for a citizen of country $i$ with cost type $c$ is given by the following matrix, where the row represents the choice of leader $i$ and the column represents the choice of leader $j$.

\begin{tabular}{ccc}
\hline & $A$ & $P$ \\
\hline$A$ & $-c$ & $\mu-c$ \\
$P$ & $-d$ & 0 \\
\hline
\end{tabular}

The parameter $\mu$ can be interpreted as the gain from being on the offensive, while the parameter $d$ represents the loss from being on the defensive. For example, if the aggressive strategy $A$ is to attack, then $\mu$ might represent a "first mover advantage", net of any cost imposed on the aggressor by the international community, while $d$ is the opponent's cost of being attacked. If instead $A$ represents the test firing of a missile, then $\mu$ might represent the utility gain from increased bargaining power, net of the cost of sanctions brought about by the missile test, while $d$ represents the corresponding loss of bargaining power for the opponent. We assume $0<\mu<d$, so the marginal incentive to choose $A$ is highest when the opponent chooses $A$. This "strategic complementarity" captures the intuition, fundamental to "Schelling's dilemma", that conflicts can escalate. We are interested in how political systems mitigate or exasperate the tendency towards escalation.

A citizen of cost type $c$ is a hawkish type if $c<\mu$. For the hawkish citizen, $A$ is a dominant strategy, because $\mu-c>0$ and $-c>-d$. The fraction of citizens who are hawks is $F(\mu)$. A citizen of cost type $c$ is a dovish type if $c>d$. For the dovish citizen, $P$ is a dominant strategy, because $-d>-c$ and $0>\mu-c$. Notice that a dove is an extreme pacifist who wants his leader to be peaceful even when the opponent is aggressive. The fraction of citizens who are doves is $1-F(d)$. A citizen of cost type $c$ is a coordination type if $\mu<c<d$. For the coordination type, the best response to $A$ is $A$, and the best response to $P$ is $P$. Coordination types capture the idea that behavior may be driven by fear: although they prefer the outcome $P P$ to the outcome $A A$, they want their leader to choose $A$ if they fear the opponent will choose $A$. The fraction of citizens who are coordination types is $F(d)-F(\mu)$.

Assumption $1 \underline{c}<\mu<c^{\text {med }}<d<\bar{c}$. 
Assumption 1 implies that the median citizen is a coordination type. Thus, if the representative (median) citizen in each country could directly choose either $A$ or $P$, the resulting game would be a coordination game with two Nash equilibria $A A$ and $P P$. We assume $P P$ is the risk-dominant equilibrium in this game, in the sense that $d-c^{\text {med }}<c^{\text {med }}-\mu$. This means that the representative citizen thinks the gain from choosing $P$ when the other country is peaceful $\left(c^{\text {med }}-\mu\right)$ exceeds the loss from choosing $P$ when the other is aggressive $\left(d-c^{\text {med }}\right) .{ }^{4}$

Assumption $2 d-c^{\text {med }}<c^{\text {med }}-\mu$.

War is often thought of as a prisoner's dilemma where, in our terminology, all decision makers are dominant strategy hawks. See Nye's [55] (p. 18-19) discussion of the Peloponnesian War, Snyder's [65] discussion of World War I, Snyder and Diesing [66] for other historical examples, and Axelrod [4] for a general discussion. ${ }^{5}$ More recent contributions, such as Baliga and Sjöström [6], allow coordination types as well. Here, we go one step further and also allow the existence of pacifistic doves, who do not favor going to war even if they are sure the other country will attack. However, the generalization is modest: our final assumption states that the doves do not outnumber the hawks.

Assumption $3 F(\mu)>1-F(d)$.

In our model of political regimes, the influence of a group of citizens will be proportional to its size. By Assumption 3, hawks will be more likely to be pivotal than doves. More generally, the relative importance of hawks and doves could be derived from a model where different citizens have different ability to influence or coerce others. A "political bias" akin to Jackson and Morelli [40] would result if hawks had disproportionate political power. Our current model is simpler, and in view of the previous literature (which emphasizes hawks and, sometimes, coordination types) Assumption 3 does not seem unreasonable.

\subsection{Political Regimes}

After the two leaders have chosen their strategies, each citizen decides whether or not to support his leader. The decision is retrospective, as in Barro [8] and Ferejohn [29]. In effect, the citizen acts as a "principal" who rewards or punishes the "agent" (the leader). Thus, a citizen of country

\footnotetext{
${ }^{4}$ The global games approach of Carlsson and van Damme [17] justifies using the risk-dominance criterion to refine the set of Nash equilibria. Chassang and Padro-i-Miguel [19], [20] use this approach to study conflict. In global games, types are highly correlated, a reasonable assumption for conflicts over a contested resource such as a piece of land. In contrast, we assume types are independent, a reasonable assumption if the types represent idiosyncratic preference shocks (private costs and benefits from going to war). As shown in Section 3.3, the condition $d-c^{\text {med }}<c^{\text {med }}-\mu$ generates the democratic peace. But our analysis of political survival would be relevant also with correlated types.

${ }^{5}$ More recent theories of war emphasize that a player may prefer to fight a war rather than making concessions, if concessions lead to adverse shifts of power (Fearon [26], [27] and Powell [59]).
} 
$i$ supports leader $i$ if and only if leader $i$ 's action was a best-response to leader $j$ 's action according to the citizen's own preferences (as given by (1)).

Following Bueno de Mesquita et. al. [13], a political system is characterized by a critical fraction of support $\sigma_{i}^{*} \leq \frac{1}{2}$ which leader $i$ needs to stay in power. ${ }^{6}$ The value of staying in power is the "rents from office", denoted $R>0$. Our theory assumes all political regimes generate the same $R$, in order to focus on the impact of political institutions on the incentives to go to war. To rule out "corner" equilibria, where even the most aggressive leaders (cost type $\underline{c}$ ) choose $P$, we assume $R<\mu-\underline{c}{ }^{7}$

If both leaders choose the same action, then each leader is supported by his median citizen. That is, each leader has the support of at least half the population, which is sufficient to remain in power in any political regime (as $\sigma_{i}^{*} \leq 1 / 2$ ). Suppose instead that the two leaders miscoordinate, say leader 1 chooses $A$ and leader 2 chooses $P$. Then, neither leader is supported by his median citizen. Indeed, leader 1 is supported by a fraction $F(\mu)<1 / 2$ of his citizens (the hawks), while leader 2 is supported by a fraction $1-F(d)<1 / 2$ of his citizens (the doves). Thus, leader 1 remains in power if $F(\mu) \geq \sigma_{1}^{*}$, and leader 2 remains in power if $1-F(d) \geq \sigma_{2}^{*}$.

Assumption 3 implies $1-F(d)<F(\mu)$. It follows that the regime of country $i$ belongs to one of three categories, depending on the size of $\sigma_{i}^{*}$. First, if $\sigma_{i}^{*}>F(\mu)$ then miscoordination always causes leader $i$ to be replaced. In other words, the support of the median citizen is necessary for leader $i$ to remain in power. Such a regime is a full democracy. Second, at the other extreme, if $\sigma_{i}^{*} \leq 1-F(d)$, then leader $i$ stays in power whatever happens. Such a regime is a dictatorship or autocracy. The third and final case is the intermediate situation, where $1-F(d)<\sigma_{i}^{*} \leq F(\mu)$. In this case, leader $i$ loses power if he chooses $P$ while the opponent chooses $A$, but he stays in power otherwise. Since this regime is intermediate between the dictatorship and the full democracy, we label it limited democracy.

In a full democracy, since the median voter is a coordination type, leader $i$ enjoys rents from office if and only if he matches the action of the opponent. Therefore, if country $i$ is a full democracy, leader $i$ 's payoff matrix is

\begin{tabular}{ccc}
\hline & $A$ & $P$ \\
\hline$A$ & $R-c_{i}$ & $\mu-c_{i}$ \\
$P$ & $-d$ & $R$ \\
\hline
\end{tabular}

where $c_{i}$ is his own cost type. (The row represents leader $i$ 's own choice, the column leader $j$ 's choice.) In a limited democracy, leader $i$ can stay in power except when he chooses $P$ and the

\footnotetext{
${ }^{6}$ The case where the leader needs a supermajority $\sigma_{i}^{*}>1 / 2$ to stay in power is not very interesting and is not considered here.

${ }^{7}$ There is a unique, interior, equilibrium as long as $F$ is concave and $R<\mu-\underline{c}$. If $F$ is concave but $R>\mu-\underline{c}$, then equilibrium for a dyad of two full democracies will be at a "corner", where even the most aggressive type plays $P$, because huge rents from office trump all other concerns. This is an extreme version of the "democratic peace". Leaders of other regime types could still play $A$, however, so replacing one of the democracies by a different regime would increase the probability of conflict. Even if we allow for multiple equilibria, there is a sense in which our main results go through: see Remark 4.
} 
opponent chooses $A$. Therefore, if country $i$ is a limited democracy, then leader $i$ 's payoff matrix is

\begin{tabular}{ccc}
\hline & $A$ & $P$ \\
\hline$A$ & $R-c_{i}$ & $R+\mu-c_{i}$ \\
$P$ & $-d$ & $R$ \\
\hline
\end{tabular}

In a dictatorship, the leader's payoff function is simply given by (1), where $c=c_{i}$ is his own cost type.

\subsection{Equilibrium}

Country $i$ 's regime type is denoted $T_{i} \in\{D e, D i, L i\}$, corresponding to full democracy (De), dictatorship (Di) and limited democracy (Li). Leader $i$ knows the regime type of country $j$ but not the cost type of leader $j$. Leader $i$ 's optimal decision depends on his own cost type, his own regime type, and the probability $p_{j}$ that leader $j$ plays $A$.

First, if country $i$ is a dictatorship, then the payoffs of leader $i$ are given by (1). Hence, leader $i$ prefers $A$ if

$$
-c_{i}+\left(1-p_{j}\right) \mu \geq-d p_{j}
$$

The leader of country $i$ must follow a cutoff strategy, playing $A$ if and only if $c_{i} \leq \mu+(d-\mu) p_{j}$. Therefore, the probability that leader $i$ chooses $A$ is $p_{i}=h\left(p_{j}, D i\right)$, where

$$
h\left(p_{j}, D i\right) \equiv F\left(\mu+p_{j}(d-\mu)\right) .
$$

The function $h(\cdot, D i)$ can be thought of as a dictator's best response function.

Second, if country $i$ is a limited democracy, then leader $i$ 's payoffs are given by (3). Hence, leader $i$ prefers $A$ if

$$
R-c_{i}+\left(1-p_{j}\right) \mu \geq-p_{j} d+\left(1-p_{j}\right) R,
$$

which is true if and only if $c_{i} \leq \mu+p_{j}(d-\mu)+p_{j} R$. Therefore, the probability that leader $i$ chooses $A$ is $p_{i}=h\left(p_{j}, L i\right)$, where

$$
h\left(p_{j}, L i\right) \equiv F\left(\mu+p_{j}(d-\mu)+p_{j} R\right) .
$$

This is the best response function for the leader of a limited democracy.

Third, if country $i$ is a full democracy, then leader $i$ 's payoffs are given by (2). Hence, leader $i$ prefers $A$ if

$$
p_{j} R+\left(1-p_{j}\right) \mu-c_{i} \geq-p_{j} d+\left(1-p_{j}\right) R
$$

which is true if and only if $c_{i} \leq \mu+p_{j}(d-\mu)+p_{j} R-\left(1-p_{j}\right) R$. Therefore, the probability that leader $i$ chooses $A$ is $p_{i}=h\left(p_{j}, D e\right)$, where

$$
\left.h\left(p_{j}, D e\right) \equiv F\left(\mu+p_{j}(d-\mu)+p_{j} R-\left(1-p_{j}\right) R\right)\right) .
$$


This is the best response function for the leader of a full democracy.

Since $F$ is concave, the best response functions $h\left(p_{2}, T_{1}\right)$ and $h\left(p_{1}, T_{2}\right)$ are concave and intersect only once. The intersection represents the unique Bayesian Nash equilibrium in the game between the two leaders. In equilibrium, leader $i$ chooses $A$ with probability $p_{i}$. Our assumptions guarantee that $0<p_{i}<1$. There is a conflict between countries $i$ and $j$ if at least one leader chooses $A$. Thus, the probability of conflict is $w_{i j}=p_{i}+\left(1-p_{i}\right) p_{j}$, which is increasing in $p_{i}$ and $p_{j}$. For a pair of regime types $T_{i}, T_{j} \in\{D e, D i, L i\}$, we denote the equilibrium probability of conflict by $w_{T_{i} T_{j}}$.

The equilibrium, for various regime types, is illustrated in Figure 1. Country $j$ 's probability of playing $A$ is given on the horizontal axis and country $i$ 's on the vertical axis. Notice that $h\left(p_{j}, L i\right)>h\left(p_{j}, T_{i}\right)$, for any $T_{i} \in\{D e, D i\}$ and any $p_{j} \in(0,1)$. That is, leader $i$ is strictly more likely to choose $A$ if country $i$ is a limited democracy rather than some other regime type. Thus, replacing any other regime type with a limited democracy shifts the best-response curve to the right. Figure 1 reveals that in the new equilibrium, both countries will be strictly more likely to choose $A$. For example, if country $i$ changes from a dictatorship to a limited democracy, the best response function changes from $h\left(p_{i}, D e\right)$ to $h\left(p_{i}, L i\right)$, and the fear-spiral will produce higher levels of both $p_{i}$ and $p_{j}$. Thus, we have the following result (which does not require Assumption 2):

Proposition 1 (Hawkish Limited Democracy) Replacing any other regime type in country $i$ with a limited democracy increases the equilibrium probability of conflict, whatever the regime type in country $j$.

We can interpret this proposition in terms of Schelling's dilemma. Since $F$ is strictly increasing, $R>0$ and $d>\mu$, the best-response function of leader $i$ is always increasing in $p_{j}$. That is, actions are strategic complements. First suppose both countries are dictatorships, so domestic political support is irrelevant. For a hawk (with cost type less than $\mu$ ), $A$ is the dominant strategy. Eliminating his dominated strategy $P$, we conclude that $A$ is played with at least probability $F(\mu)$. After this first round of elimination of dominated strategies, $P$ becomes dominated for some other types. Specifically, consider any type $c_{i}$ such that

$$
c_{i}<\mu+F(\mu)(d-\mu)
$$

Using (4), this type of dictator must play $A$, knowing that $p_{j}$ (the probability the opponent plays $A$ ) is at least $F(\mu)$. Eliminating $P$ for all types (of both dictators) such that (10) holds makes $P$ dominated for yet more types. This process of elimination of dominated strategies, this "fear spiral", causes more and more high-cost (peaceful) types to play A. This is Schelling's dilemma (see Baliga and Sjöström $[6]){ }^{8}$

\footnotetext{
${ }^{8}$ Our theory assumes leaders choose simultaneously. It can be generalized along the lines of Jun Xue [78] to allow sequential moves. Suppose action $A$ has some physical manifestation, such as the firing of a missile or an actual invasion, while $P$ represents "doing nothing". In this case, $P$ can be easily reversed (it is not a commitment to playing $P$ in the future), but $A$ cannot be so reversed. In equilbrium, all types are peaceful initially, but some switch to aggression, creating a fear spiral as in the static model.
} 
Now suppose the regime in country $i$ changes from dictatorship to limited democracy. The leader of a limited democracy is ousted if he plays $P$ when the opponent plays $A$. To see how this "hawkish bias" reinforces Schelling's dilemma, again notice that a hawkish type of leader $j$ surely plays $A$, so $p_{j} \geq F(\mu)$. But now, the second round of elimination of dominated strategies involves more types. Specifically, consider any type $c_{i}$ of leader $i$ such that

$$
c_{i}<\mu+F(\mu)(d-\mu)+F(\mu) R .
$$

By (6), this type must play $A$, knowing that $p_{j} \geq F(\mu)$. Thus, in the second round we eliminate $P$ for all types such that (11) holds. Comparing (11) with (10), we find that $P$ is eliminated for more types in a limited democracy. The difference is due to the term $F(\mu) R$, which represents the rents from office the leader of a limited democracy loses if he plays $P$ when leader $j$ plays $A$. By the same argument, in each "round" of elimination more types eliminate $P$ when country $i$ is a limited democracy (and by strategic complementarity, the same holds for country $j$ ). This exasperates Schelling's dilemma.

Now suppose the regime in country $i$ changes from limited democracy a full democracy. After this transition, $P$ can be eliminated by fewer types in each round of elimination of dominated strategies. This is due to the rents from office the leader of a full democracy loses if he plays $A$ when leader $j$ plays $P$. Therefore, in each round fewer types eliminate $P$ when country $i$ is a limited democracy (and by strategic complementarity, the same holds for country $j$ ). This mitigates Schelling's dilemma. Conversely, changing from a full democracy to a limited democracy exasperates the dilemma and creates conflict.

Having identified the least peaceful dyad in Proposition 1, we now consider which dyad is most peaceful. Clearly, by Proposition 1 we may focus on dyads that do not include any limited democracy. It can be checked that $h(p, D e)$ and $h(p, D i)$ have a unique intersection at $p=1 / 2$ (see Figure 2). If $p>1 / 2$ then $h(p, D e)>h(p, D i)$. Thus, when facing an aggressive opponent who is likely to play $A$, the leader of the full democracy is more likely to choose $A$ than a dictator (hawkish bias), because he loses power if he responds to $A$ with $P$. On the other hand, if $p<1 / 2$ then $h(p, D e)<h(p, D i)$. Thus, when facing a peaceful opponent who is likely to play $P$, the leader of the full democracy is more likely to choose $P$ than a dictator (dovish bias), because he loses power if he responds to $P$ with $A$. Now, the intersection of $h(p, D e)$ and $h(p, D i)$ lies below the 45 degree line:

$$
h\left(\frac{1}{2}, D i\right)=h\left(\frac{1}{2}, D e\right)=F\left(\frac{d+\mu}{2}\right)<F\left(c^{m e d}\right)=\frac{1}{2},
$$

where the inequality uses Assumption 2. Because of this, as can be seen in Figure 2, each leader in a dyad that excludes limited democracies chooses $A$ with probability less than $1 / 2$. In this region, the fully democratic leader has a dovish bias, so $w_{D e D e}<w_{D e D i}<w_{D i D i}$. Thus, we have:

Proposition 2 (Dyadic Democratic Peace) A dyad of full democracies is more peaceful than any other pair of regime types. 
Despite the dyadic democratic peace, there are many historical examples of democracies going to war against less democratic states. In our model, the equilibrium probability of conflict increases dramatically when a dyad of two full democracies changes to a mixed dyad with just one full democracy, for two reasons. First, the less democratic regime will not have a dovish bias, making it more likely to choose $A$. But this triggers the second effect: the democratic leader's dovish bias disappears, because the median voter wants him to respond to $A$ with $A$. Formally, the Appendix shows that since the best response function of a full democracy has the steepest slope, the impact of increased fear is especially large. As aggression feeds on itself (strategic complements), Schelling's dilemma implies that the equilibrium probability of conflict increases very rapidly:

Proposition 3 (Democracies Turn Hawkish) As country $j$ changes from a full democracy to any other regime type $T^{\prime} \in\{D i, L i\}$, the equilibrium probability of conflict increases more if country $i$ is a full democracy than if it is any other regime type $T \in\{D i, L i\}$. That is,

$$
w_{D e T^{\prime}}-w_{D e D e}>w_{T T^{\prime}}-w_{T D e} .
$$

We end the theoretical discussion with two remarks.

Remark 4 If $F$ is not concave, there may be multiple Bayesian Nash equilibria, but Schelling's dilemma must apply to all of them: dominant strategy hawks always choose A, causing other types to choose A, etc. Moreover, our qualitative results go through in the following sense. As actions are strategic complements, by familiar arguments there is a "lowest" and a "highest" equilibrium (in terms of probability of aggression), and all other equilibria lie between them (c.f. Vives [74]). But $p_{j} \in(0,1)$ in any equilibrium implies $h\left(p_{j}, L i\right)>h\left(p_{j}, T_{i}\right)$, for any $T_{i} \in\{D e, D i\}$. This implies that replacing any other regime type with a limited democracy increases the probability of conflict both at the lowest and highest equilibrium. In this sense, our results can be extend to the case of multiple equilibria.

Remark 5 At the heart of Schelling's dilemma is the behavior of coordination types, i.e., types who want peace but will act aggressively if they fear the opponent will be aggressive. But suppose both leaders were commonly known to be coordination types, in the sense that $d>c_{i}>\mu$. It can be verified that, for any pair of regime types, there will be two pure-strategy Nash equilibria: AA and PP. But which equilibrium will be played: the "trusting" equilibrium PP or the "fearful" equilibrium $A A$ ? In our model, this indeterminacy vanishes because of the reasonable assumption that each player is not quite sure that the opponent is a coordination-type. Incomplete information and the possibility of dominant strategy types leads to a unique "interior" equilibrium, by the spiralling argument outlined above. Moreover, in this equilibrium the marginal incentive to be aggressive depends on the regime type. The combination of incomplete information and incentives for domestic political survival thus generates the relationship between political institutions and conflict. 


\section{Empirical Analysis}

We first describe the data, then the empirical model, and finally discuss the estimation results.

\subsection{Data}

\subsubsection{Conflict Data}

We use data on militarized interstate disputes (MIDs) from the Correlates of War [43] project (COW, hereafter). This dataset is an unbalanced panel that provides information on MIDs among approximately 190 states, at annual frequency, starting in 1816 and ending in 2000. Militarized disputes include interstate wars, but also threats, demonstrations of force, and other hostile interstate actions. This broad interpretation of conflict, which increases the frequency of conflicts in the data, is consistent with our theoretical model. The COW has been the predominant data source in the empirical literature on the democratic peace hypothesis (e.g., Oneal and Russett [56]). In its monadic form, the COW records, for each year, whether a country is involved in an MID. But in our theory, the incentive to be aggressive depends on the regime types of pairs of countries. We therefore use the dataset in a dyadic form, which contains conflict information for each possible pair of countries in the system. ${ }^{9}$

Our theoretical model is a static game. It doesn't identify one country as having initiated the conflict (both may have chosen $A$ ), neither does it predict the duration of conflicts or coalition formation in multilateral disputes. Therefore, we estimate the probability of conflict for country pairs using the so-called "undirected" form of the data, and we drop all dyad-year observations corresponding to either an ongoing dispute or a country joining an ongoing dispute.

\subsubsection{Classifying Regime Types}

Data on political regime characteristics are from the Polity IV dataset (Monty and Gurr [54]). Indexes measuring the competitiveness of political participation, competitiveness of the process for selecting the chief executive, regulation of political participation, openness of executive recruitment and constraints on the chief executive are used to construct democracy and autocracy scores ranging from 0 to 10 for each regime. We follow previous literature (Oneal and Russett [56] among many others) and take the difference between the democracy and the autocracy index to calculate a "net democracy" score, and use its values to classify countries as dictatorships, limited democracies or full democracies. Very high values of the score signal strong democratic institutions with strong checks on the leader's power. Very low values, instead, suggest the absence of any controls on the leader. Intermediate values of the score correspond to regimes in which some limits on the leader's power exist, but not enough for the regime to qualify as fully democratic. We will use

\footnotetext{
${ }^{9}$ Data for the historical period 1816-1992 in the COW are available in monadic form, and forming the dyadic data requires additional information not reported in the original dataset. Zeev Maoz [52] has augmented the standard monadic COW dataset and constructed a dyadic dataset for the years 1816-1992. The COW v 3.02 contains militarized dispute data in dyadic form for the remaining years 1993-2000 included in our sample.
} 
such intermediate values to define limited democracies. This approach has also been used in other studies that focus on regimes in this middle range, sometimes known as "anocracies" or "mixed regimes" (see Gurr [36], Goemans [33] and Mansfield and Snyder [51]). ${ }^{10}$ The net democracy index from Polity IV ranges from -10 to 10, taking 21 possible values in all. In the baseline model, we divide the range of possible net democracy scores into three sub-intervals of equal length. Thus a dictatorship corresponds to values smaller than -3 , a limited democracy to values between -3 and 3 , and a full democracy to values greater than 3 .

A few examples can illustrate the category of "limited democracies." Germany in the late nineteenth and early twentieth century is a limited democracy. Power was concentrated in the hands of the kaisers, but they could not repress the views of the population entirely. Under Wilhelm II, the Socialist party formed a strong voting block in the Reichstag and even won the general elections in 1913 (Craig [21], Chapter 8). Louis-Philippe, "King of the French", was appointed by France's Chamber of Deputies after the July Revolution of 1830 (Howarth [39]). During much of his reign, France is a limited democracy. Napoleon III initially ruled dictatorially, but from the 1860s he gave the French Parliament more power (Wetzel [76]). By 1870, France is classified as a limited democracy in our data.

Table 1 lists the countries, from the sample used to estimate the baseline model, that are classified as limited democracies for the longest period of time. In addition to the major European powers, Latin American countries such as Ecuador, Peru, Chile and Argentina are heavily represented. Ecuador is classified as a limited democracy for the longest amount of time, 114 years between 1854 and 1971. Middle Eastern countries begin to appear in this classification in the postwar period. Anecdotal evidence, and the results in Mansfield and Snyder [51], suggest that these limited democracies may be highly prone to conflict. Mansfield and Snyder [51] argue that conflicts are likely to occur during transitions to democracy. In fact, our empirical findings will suggest that limited democracies are inherently more aggressive, and not just during periods of political regime transitions.

Table 2 reports the list of limited democracies that were engaged most frequently in disputes. Latin American countries such as Argentina, Ecuador, Nicaragua and Peru, are heavily represented in both the nineteenth and twentieth centuries. In the nineteenth century, the great European powers are limited democracies and are heavily involved in disputes. In Asia, Japan and Thailand are involved in conflicts frequently. In Africa and the Middle East, countries like Kenya and Jordan are limited democracies for a short period of time but engage in disputes relatively frequently during that period.

Table 3 lists the dyads of limited democracies that were the most conflict-ridden. Latin American countries experienced many conflicts with European powers as well as with each other. For example, Ecuador and Peru repeatedly fought over the Condor Mountain range (Simmons [64]). The late 1930s and early 1940s marked a violent turning point in this conflict and, during this

\footnotetext{
${ }^{10}$ The COW data and the Polity data, along with other controls considered in the democratic peace literature, are available from Scott Bennett's EUgene website: http://eugenesoftware.org, or through datasets from Bruce Russett's web-page: http://pantheon.yale.edu/\%7Ebrusset/.
} 
period, both countries are classified as limited democracies. Bolivia-Paraguay and Argentina-Chile are other conflict-ridden dyads of limited democracies. Japan has participated in many conflicts with various opponents. Many of these disputes occurred during the nineteenth and the first half of the twentieth century. We return to this issue below, when we analyze the estimates of the model over shorter time subsample.

\subsection{Empirical Model}

Our empirical strategy has two steps. We first utilize the Polity net democracy score to construct a set of dummy variables that characterize the regime types of each dyad in the sample. We then estimate the probability that a militarized dispute (MID) occurs within each possible dyad. The explanatory variables include the regime type dummies and controls typically considered in the democratic peace literature. Our preferred estimation procedure is a panel logit regression model with fixed effects at the dyadic level. This simple methodology allows us to study the effects of democracy on conflict using a flexible functional specification that links conflict to political regime types. It is particularly well suited for investigating a possible non-monotonic relation between democracy and conflict. The dyadic fixed effects control for time-invariant sources of unobserved heterogeneity, such as historical enmities between countries, or geographical distance.

The main restriction imposed by our methodology is the initial classification of regimes into dictatorships (net democracy scores below -3), limited democracies (scores between -3 and 3), and full democracies (scores above 3). As a robustness check, we consider a broader definition of a limited democracy, corresponding to net democracy scores between -6 and 6 as well as others. Some countries which never meet the narrower definition, like Spain, meet the broader definition in some years. Other countries, like France, meet the narrower definition during certain years but meet the broader definition more often.

There are six possible configurations of regime types for a dyad. As shown in Table 4, we define a corresponding set of six dummy variables where $J \equiv\{D i D i, D i L i, D i D e, L i L i, L i D e, D e D e\}$, representing dyad types ranging from a pair of dictatorships ( $D i D i)$ to a pair of full democracies $(D e D e)$, as well as all other possible combinations of regimes. The dummy variable $D_{j}$ equals one $\left(D_{j, d t}=1\right)$ if at time $t$ dyad $d$ is composed of a pair of regime types $j \in J$ (and zero otherwise). For our baseline definition of a limited democracy, the composition of dyad types varies from a maximum of 31 percent, for a democracy-dictatorship pair, to 6 percent for a limited democracy pair (see Table 5). ${ }^{11}$

To maximize the amount of data, we consider MIDs rather than wars. Even so, MIDs are rare events. For instance, in our baseline model, which only considers dyads for which at least one dispute occurred in the data (see below), a total of 40,786 observations are included but only 5 percent of these involve MIDs (see Table 5).

Let $M I D_{d t}=1$ if dyad $d$ experienced a military dispute at time $t$, and $M I D_{d t}=0$ otherwise.

\footnotetext{
${ }^{11}$ As discussed later in this section, the baseline model only includes dyads for which at least one MID occurred in the data.
} 
Our baseline empirical model is a logit model that identifies the conditional probability of a MID for dyad $d$ at time $t+1$ by:

$$
\operatorname{Prob}\left\{M I D_{d t+1}=1 \mid\left\{D_{j, d t}\right\}_{j \neq L i L i}, \mathbf{X}_{d t}, c_{d}\right\}=G\left(c_{d}+\beta^{\prime} \mathbf{X}_{d t}+\sum_{j \neq L i L i} \gamma_{j} D_{j, d t}\right),
$$

where $\mathbf{X}_{d t}$ is a vector of controls, $c_{d}$ is a fixed effect defined at the dyadic level and $\left\{D_{j, d t}\right\}_{j \neq L i L i}$ are all regime type dummy variables with the exception of the limited democracies pair. ${ }^{12}$ The fixed effects account for unobserved heterogeneity arising from factors such as geography and persistence of culture and institutions in the cross-section of dyads. ${ }^{13}$

A logit regression model's parameters are not identified if a subset of regressors perfectly predicts the outcome of the dependent variable. Since we include both dyadic and year fixed effects in model (13), only country pairs for which at least one MID occurs in the sample period can be included in the estimation; in addition, any year in which no MID occurred is also excluded. ${ }^{14}$ To reduce issues of reverse causality in situations where regime transitions and disputes occur during the same year, we lag explanatory variables by one period, as noted by the time subscripts in (13). In addition, since the parameter coefficients on the entire set of dummies $J$ cannot be separately identified from the constant term, we exclude the dummy $D_{L i L i, d t}$ in model (13).

To estimate the parameters in (13), we use Chamberlain's [18] conditional maximum likelihood procedure, which yields consistent estimates of all parameters except the fixed effects (the $c_{d}$ 's). For $j \neq L i L i$, the coefficient $\gamma_{j}$ on dummy variable $D_{j}$ measures the partial effect of regime type $j$ relative to a pair of limited democracies. However, because the magnitude of the partial effects depend on the fixed effects which are not estimated, we only obtain an ordinal - rather than a cardinal - ranking of the conflict propensity of each dyadic type. For example, a negative value for $\hat{\gamma}_{D i D i}$ implies that a dyad of dictatorships is less likely to experience a conflict than a dyad of limited democracies, but the parameter estimate does not reveal the absolute magnitude of the effect. ${ }^{15}$

Returning to the theoretical model, Proposition 1 implies that a dyad consisting of two limited democracies is the most conflict-ridden, so all coefficients $\hat{\gamma}_{j}$ should be negative. Proposition 2 implies that a dyad consisting of two full democracies is the most peaceful, so we should have

\footnotetext{
${ }^{12}$ The function $G(\cdot)$ is the c.d.f of the logistic distribution. For a review of qualitative response models, and their panel specifications see Wooldridge [77].

${ }^{13}$ For example, the colonial origin of countries in Africa and South America has played a large role in their subsequent development. See Acemoglu and Robinson [1] for a review of much of this work.

${ }^{14}$ The maximized value function of the likelihood would be unbounded if these observations were instead included in the estimation (see e.g. Albert and Anderson [2]). The years excluded from the sample are 1818, 1819, 1827, 1841, 1843, 1866, and 1891. The corresponding number of observations are less than 0.5 percent of the total.

${ }^{15}$ Hatted variables denote estimates of the corresponding parameters. The partial effect of a dyad of type $j$ relative to a pair of limited democracies is:

$$
G\left(c_{d}+\hat{\beta}^{\prime} \mathbf{X}_{d t}+\hat{\gamma}_{j}\right)-G\left(c_{d}+\hat{\beta}^{\prime} \mathbf{X}_{d t}\right)
$$

Although absolute magnitudes of these partial effects cannnot be estimated when the $c_{d}$ 's are not estimated, the $\hat{\gamma}_{j}$ 's order the partial effects in terms of relative magnitudes.
} 
$\hat{\gamma}_{D e D e}<\hat{\gamma}_{j}$ for all $j \neq D e D e$. Finally, Proposition 3 implies that if a country ceases to be fully democratic, the probability of conflict increases most in those dyads where it is matched with a full democracy. Proposition 3 cannot be tested in our baseline model, because we do not estimate the fixed effects. Instead, we estimate the parameters of (13) using two alternative procedures: a pooled logit model, which excludes fixed effects, and a linear probability model, where $G(\cdot)$ is an identity map. ${ }^{16}$

The set of controls $\mathbf{X}_{d t}$ includes year fixed effects to account for time varying factors that are common to all dyadic pairs (e.g. the number of countries in the system, worldwide economic shocks, worldwide conflicts.) Further, we include cubic spline terms in the number of years since a country pair was last involved in a conflict, in order to capture the temporal dependence of militarized disputes on past occurrence of disputes within a pair of countries with a flexible functional specification. ${ }^{17}$ We follow earlier literature on democratic peace (e.g. Oneal and Russett [56]) in selecting the remaining controls. First, major powers may have an increased incentive to engage in a MID if they think they can escape retaliation, but they may be less aggressive if they can achieve their objectives without conflict. These effects are captured by the dummy variable MajPower, which is equal to one if at least one of the two countries is a major power at time $t$. Second, an imbalance of military power may create conflict (Bremer [15]). The COW dataset contains an index of military capabilities, constructed from measures of urban and total population, energy consumption, iron and steel production, military manpower and expenditure. The variable LogCapRatio that we include in the regressions is the logarithm of the maximum to the minimum level of military capabilities within each country pair taken from the COW dataset. Third, if two countries in a dyad are formally allied by a non-aggression or neutrality treaty, the Alliance dummy variable equals one. We discuss details of the other controls used in the robustness checks below.

\subsection{Empirical Results}

Estimates of the parameters of the empirical models are shown in Tables 6, 9 and 11. Each table shows the empirical estimates in two panels. Panel a contains two columns for each regression model. The first column reports the estimated coefficients and standard errors for all - but a pair of limited democracies - regime type dummy variables. The second column reports the $P$-value of a Wald test for the null that the estimated coefficient on the dummy $D_{j}$ is equal to that of $D_{D e D e}$, i.e. a pair of full democracies. ${ }^{18}$ Panel b reports coefficient estimates and standard errors for all additional controls included in the regression models with the exclusion of the year fixed effects

\footnotetext{
${ }^{16}$ Because of the linearity of this model specification, comparisons of conflict probabilities under different regime types are equivalent to comparing the corresponding regime dummies.

${ }^{17}$ Formal tests support the use of the year fixed effects and the spline terms. The estimated coefficient on the spline terms indicate that the probability of a MID is higher when another MID occurred in the recent past within the same dyad. The spline term specification allows to account for the temporal dependence with a flexible but parsimonious specification (four parameters in our specification, see Beck, Katz and Tucker [9] for an earlier specification of cubic spline regressions in the democratic peace literature.)

${ }^{18}$ The t-test (P-value in the first column) on $D_{D e D e}$ is asymptotically equivalent to the corresponding Wald test, and is therefore omitted from the table.
} 
and the cubic spline terms.

\subsubsection{Baseline Model}

Parameter estimates of our baseline empirical specification - the logit model with fixed effectsare shown in column Model 1 of Table 6. As it can be seen from the Table, all estimated $\hat{\gamma}_{j}$ are negative and significant at the 1 percent level. In other words, a dyad of limited democracies is more likely to experience a militarized dispute than any other dyad type. In particular, it is more conflict-ridden than a dyad of dictatorships. Also, as shown in the second column of Model 1, the estimated coefficient $\hat{\gamma}_{D e D e}$ on the regime type dummy variable $D_{D e D e}$ is the smallest amongst the dyad type dummies. The $P$-values reported in the second column show that these differences are significant at the 1 percent level. We thus confirm previous findings of a dyadic democratic peace (Babst [5], Levy [49] and Maov and Russett [53]). ${ }^{19}$ However, the parameter estimates show a non-monotonic relationship between democratization and peace, since limited democracies are the most conflict prone.

Macroeconomic factors such as measures of economic development, openness to trade and bilateral trade flows may affect the incentive to engage in conflict. ${ }^{20}$ However, reliable data on these variables are not available for the full sample, especially prior to 1945, which, as discussed in the next subsection, is a central historical period in our analysis. ${ }^{21}$ Moreover, the two sets of fixed effects included in our baseline specification help capturing in part the impact of these variables. First, the year fixed effects can account for worldwide economic shocks and business cycles. Hence, economic fluctuations which are common to both members of a dyad and affect their incentives to be aggressive are captured by the year fixed effects. Furthermore, the dyadic level fixed effects account for some important factors, such as the relative disparity of natural resource endowments and geographic distance, which are largely time-invariant but affect the likelihood of conflict through their impact on variables such as dyadic trade flows and the degree of disparities in national income.

\subsubsection{Alternative Empirical Specifications}

We now consider two alternative empirical models: a linear probability model with fixed effects and a pooled logit model. These models allow us to assess the robustness of our baseline results.

\footnotetext{
${ }^{19}$ Only the dummy for alliance treaties is statistically different from zero among the additional controls included in the model. The existence of a treaty reduces the likelihood of a MID within the dyad.

${ }^{20}$ Different political indicators for classification of regime types might be another variation worth considering. The most obvious choice is the index from the Freedom House Project [30]. This data has been used in theoretical and empirical studies of democratization and economic development (see Acemoglu and Robinson's [1] book for an overview of this literature). However, this data is only available starting in 1972. The results confirm our results for the post World War II subsamples reported in a later section.

${ }^{21}$ We augmented the baseline model specification to include a measure of dyadic trade among the set of controls (using historical data from Barbieri [7]). The estimated coefficient on dyadic trade was never statistically different from zero. Moreover, due to missing observations, the sample size dropped by more than two thirds relative to the baseline model, and due to the missing data, only the years 1871-1992 are included in the estimation. In addition, we also included measures of GDP per-capita in PPP, restricting our sample to the post 1950 sample. All regime type dummies remained negative, although the point estimates were much noisier than in the full sample. These results are similar to the ones for the post-World War II subsample, discussed in the next section.
} 
Moreover, they allow us to compare the magnitudes of the effect of different regime types on the probability of conflict. This allows us to test the prediction made in Proposition 3.

Robustness and Further Results The estimates of the linear probability model with dyadic fixed effects are shown in Table 6. From the first column under Model 2 of Panel a, all estimated coefficients on the regime type dummies are negative and significantly different from zero. Further, the coefficient on $D_{D e D e}$ is the smallest and significantly so, as shown from the P-values in the second column. As in the baseline model, a pair of limited democracies is most likely to engage in a MID, and a dyad of full democracies is least likely. Because of the linearity of the model, the partial effects of the different regime types relative to the limited democracy pair are equal to the coefficients on each regime type dummy $D_{j}$. To interpret these magnitudes, note that the probability of conflict in the sample of observations used to estimate the linear model is significantly smaller than in the sample used to estimate the baseline model. Indeed a large number of dyads that never engaged in a MID are included in this model, but were excluded in the estimation of the conditional logit model..$^{22}$ The probability of conflict for a pair of limited democracies is equal to $0.0075 .^{23}$ The likelihood that a dyad engages in a MID falls by 36 percent when a dyad changes from a pair of limited democracies to a pair of dictatorships, and it falls by 95 percent when a dyad changes from a pair of limited democracies to a pair of full democracies. However, we should point out that, due to the very low frequency of MIDs in the sample and the linearity of the model, a large portion of fitted probabilities implied by the parameter estimates (in fact the lowest half) turn out to be negative.

The pooled logit regression model (Model 3 in Table 6) always predicts probabilities between zero and one, but it excludes dyadic fixed effects. Instead we enlarge the set of controls to include other standard measures used in the democratic peace literature. In particular, we include two measures of distance: the logarithm of the distance between the two countries' capitals, LogDist, and a dummy variable, Contig, which indicates whether the country pair shares contiguous borders. Unlike the other two models, both within and between-dyadic variation in the data is used to estimate the model parameters. Further, as for the linear probability model, all parameters are estimated and it is thus possible to quantify the magnitudes of the partial effects associated with the different regime types. As shown in Table 6, a dyad of limited democracies is again the most conflict-ridden, and a dyad of full democracies is the most peaceful (all results are significant at conventional levels). ${ }^{24}$ Table 7 displays the magnitudes of the partial effects of each regime type relative to the limited democracy pair. As shown, all partial effects are significant at conventional

\footnotetext{
${ }^{22}$ The unconditional probability of an MID is 0.0054 in the sample used to estimate the linear model, compared to 0.05 in the sample of the baseline model (see Table 5).

${ }^{23} \mathrm{It}$ is constructed by setting the values of all other dummies to zero, and all remaining regressors are set at the respective sample means.

${ }^{24}$ The addition of more controls, the elimination of the fixed effects and the different estimation sample changes some of the results for the remaining controls. The Alliance dummy is no longer significant, while MajPower and LogCapRatio are now statistically significant. The parameter estimates confirm findings in the democratic peace literature: They imply that country pairs with similar military capabilities and for which at least one country is a major power, are more likely to engage in a MID.
} 
levels, with the exception of the one corresponding to $D_{D e L i}$, which is only barely significant. The magnitudes of the partial effects relative to the baseline probability are again sizable. The likelihood that a dyad engages in a MID falls 59 percent when the dyad changes from a pair of limited democracies to a pair of dictatorships, and it falls 73 percent when the dyad changes from a pair of limited democracies to a pair of full democracies.

To summarize, the estimates of the alternative empirical models confirm the baseline results of a non-monotonic empirical relation between the probability of engaging in conflict and political regime types: a dyad of limited democracies is the most likely to engage in a MID and a dyad of full democracies is the least likely. Even our more conservative estimates suggest that the limited democratization of a dyad of dictatorships more than doubles the likelihood of conflict.

Democracies turn Hawkish The three empirical specifications considered so far provide support for the dyadic democratic peace hypothesis. Here we test an additional implication of the model for full democracies. In our theory, whatever the regime type of country $i$, conflict becomes more likely when the opposing country $j$ becomes more aggressive. Proposition 3 implies that this effect is maximal when country $i$ is itself a full democracy. This prediction can be tested using the estimates of the linear probability model with fixed effects, and the pooled logit model. Table 8 displays the point estimates, and significance for the null that these estimates are zero, for the combinations of conflict probabilities, $\omega_{i j}$, that form each of the three conditions in (12). ${ }^{25}$ (The Table does not report results for the inequality in which $T=D i, T^{\prime}=L i$, which is equivalent to the inequality with $T=L i, T^{\prime}=D i$. $)^{26}$

The estimates of the linear probability model are reported in the first column of the Table. Two of the three point estimates satisfy the inequalities and are significantly different than zero. For the inequality $T=L i, T^{\prime}=L i$, the parameter estimates are too imprecise to assess whether the inequality holds. The estimates of the pooled logit model are reported in the second column of Table 8. All the point estimates of (12) satisfy the inequalities, and are statistically different than zero. We thus find evidence that full democracies turn hawkish in the sense of responding most aggressively to adverse changes in the environment. Conversely, using the estimates of the linear probability model, if a country changes from dictatorship to a full democracy, then the probability of a conflict with a full democracy decreases by 90 percent, but the probability of conflict with a dictatorship decreases by only 12 percent. $^{27}$ Thus, even full democratization does not significantly

\footnotetext{
${ }^{25}$ In the pooled and fixed effect logit model specifications, the difference in the predicted probabilities conditional on the regime pairs, which form (12), depend on all parameters including the fixed effects. Thus we cannot test the proposition using the conditional maximum likelihood estimates of the fixed effect logit model, since the fixed effects are not being estimated. In the linear probability model, instead, the difference in the conditional probabilities in (12) simplifies to the difference of the corresponding regime type dummies. In the pooled logit model, the difference is calculated by setting the value of all regressors (excluding the regime type dummies) at their sample means, as in the previous calculations of the marginal effects. The variance covariance matrix for the Wald test in the logit model is obtained by the delta method.

${ }^{26}$ That is, because of the symmetry in the model: $\left(w_{D e L i}-w_{D e D e}\right)-\left(w_{D i L i}-w_{D i D e}\right)>0$ if and only if $\left(w_{D e D i}-w_{D e D e}\right)-\left(w_{L i D i}-w_{L i D e}\right)>0$.

${ }^{27}$ As noted above, the linear probability model predicts that the probability of conflict between two limited democracies $w_{L i L i}$ is 0.0075 .
} 
lower the probability of conflict with non-democratic states.

\subsubsection{Other Empirical Results}

Alternative Regime Definitions and Transitions In our baseline analysis we divided the range of possible net democracy scores, which goes from -10 to +10 , into three intervals of equal length, with limited democracies in the interval [-3,3]. In Mansfield and Snyder [51], limited democracy instead corresponds to net democracy scores between -6 and 6. As shown in Model 6 of Table 6 , the main findings of our baseline model are confirmed if we use their classification: dyads of limited democracies are most likely to engage in a MID, while fully democratic dyads are the most peaceful. ${ }^{28}$ However, the main issue raised by Mansfield and Snyder [51] is that states that have recently been partially democratized are likely to be aggressively nationalistic during a transitional period. Accordingly, they define a transitional dummy that indicates whether a transition from a dictatorship to a limited democracy occurred in the previous 5 years. To study the effect of regime transitions, we include Mansfield and Snyder's transitional dummy in our regression, using both the $[-3,3]$ definition of limited democracy from our baseline empirical model and the broader classification $[-6,6]$.

As shown in Model 1 of Table 9, our baseline regression results are not affected when we include the transitional dummy: all regime-type dummies are still negative and significant at conventional levels. In other words, limited democracies are not only prone to conflict during a period of transition. They are more likely to be involved in conflicts even long after the transition. Our baseline results appear robust to the inclusion of the additional control: dyads of limited democracies (new and old) are most conflict-ridden, while dyads of full democracies are most peaceful. In our baseline regression, Mansfield and Snyder's [51] transitional dummy has the wrong sign (significant at the 10\% level): a recent democratization actually decreases the likelihood of conflict.

If instead we use the [-6,6] classification, there is more support for Mansfield and Snyder's [51] theory. The transitional dummy is positive and significant at the $10 \%$ level. All the coefficients on the regime-type dummies for dyads of regime types are still negative, but only two are significant at conventional levels. We conclude that the data can support both the idea that transitional periods are dangerous, and the idea that limited democracies are inherently hawkish, but one or the other theory looks better depending on the exact classification of regime types.

Polity scores are based on qualitative assessments of governing institutions. Various definitions of limited democracies in terms of Polity scores appear in the literature, e.g., Fearon and Laitin [28] use the range $[-5,5]$. In our theoretical model, the leader of a limited democracy can stay in power with the support of a hawkish minority, and it is not clear which Polity scores correspond more closely to this. Indeed, there is no reason why the definition should necessarily be symmetric around zero. In general, limited democracies can be defined as states with net democracy scores

\footnotetext{
${ }^{28}$ The empirical distribution of dyadic regime types with this alternative classification is $D_{D i D i}: 12$ percent of all observations; $D_{L i D i}: 17$ percent; $D_{L i L i}: 18$ percent; $D_{D e D i}: 19$ percent; $D_{D e L i}: 22$ percent; $D_{D e D e}: 12$ percent.
} 
in some set $[x, y] .{ }^{29}$ As a further robustness check, we reestimate the baseline conditional logit model for different values of $x$ and $y$. Specifically, $x$ takes values between -6 and -2 , and $y$ takes values between 2 and 6 , for a total of 24 alternative definitions. Table 10 summarizes the results of this analysis. Each entry enclosed in parenthesis reports the number of point estimates for the regime type dummies $D_{j}$ that are negative as well as negative and significant at the $10 \%$ levelrespectively, the first and second entry - for the corresponding definition of a limited democracy. For each alternative definition $[x, y]$ of limited democracy, the minimum net democracy score $x$ is given by the first column, and the maximum $y$ by the first row.

As indicated by the first entries enclosed in parenthesis, under all 24 definitions of limited democracy, point estimates for the coefficients of all five regime type dummies are negative for all regression models. As shown by the second entries in parenthesis, the large majority of these negative point estimates are also statistically different from zero across the alternative definitions. Thus, although the significance somewhat depends on the classifications, the point estimates indicate that limited democracies are the most conflict prone, for a broad range of possible definitions of limited democracy.

Subsamples Table 3 indicates that a large number of MIDs for limited democracy pairs occurred before World War II. Therefore, we reestimate the baseline model over two sub-samples of pre- and post-World War II data. As shown in Table 11, the results in the pre-World War II sub-sample are analogous to the ones obtained over the entire sample. All coefficients on the regime dummies are negative and significantly different from zero; the coefficient on $D_{D e D e}$ is again the smallest, and the difference with respect to $D_{D e D e}$ is significant for four of the five dummies. In the post-World War II sample, we find weaker evidence. Although the coefficients on all regime-type dummies are still negative, only one differs significantly from zero. Further, only three of the dummies now have coefficients that are significantly larger than $D_{D e D e}$. Overall, the dyadic democratic peace hypothesis seems to be supported both pre- and post-World War II. ${ }^{30}$ The hypothesis that limited democracies are inherently aggressive finds less support after World War II.

During the Cold War, there is a decline both in the number of limited democracies in our sample, and in the number of MIDs in the western hemisphere. During this special period, countries within the Soviet bloc could not act independently, and the fear of nuclear war prevented minor disputes from escalating (Gaddis, [32], p. 261-263). To study if the old patterns might return after the erosion of the Soviet bloc, we consider the sub-sample of militarized disputes after $1984 .{ }^{31}$

The details of the empirical specification are the same as in our baseline model. The estimation

\footnotetext{
${ }^{29}$ For example, for $x=-5$ and $y=3$, limited democracies are in the interval $[-5,+3]$, dictatorships are in $[-10,-6]$, and full democracies in $[+4,+10]$.

${ }^{30}$ However, if we consider only pre-World War I data, then we reproduce the result of Farber and Gowa [24], who found no evidence for a democratic peace before World War I. Thus, it is more correct to say that there is evidence in favor of a democratic peace only after World War I.

${ }^{31}$ The amount of data to estimate within country variation is very limited if we start the sub-sample with the fall of the Berlin Wall in 1989, as discussed below. Arguably, the erosion of the Soviet bloc began before 1989. In 1980, Solidarity was founded in Poland, and in 1985 Mikhail Gorbachev came to power. The year 1984 marks a mid-point between the arrival of Solidarity and the fall of the Berlin Wall.
} 
results are reported as Model 3 in Table 11. A dyad of limited democracies is again more conflict prone than any other dyad type at conventional statistical significance levels. The result holds also for the broader $[-6,6]$ definition of a limited democracy (not shown in the table). A dyad of full democracies is again the most peaceful, but the difference is statistically significant only for two regime type dummies. Model 4 of Table 11 reports the weaker support for our theory when we focus on only the post-1989 sub-sample. ${ }^{32}$ These findings are not surprising, since the parameters of our model are only identified by within-country variation of data (in terms of interstate conflict and regime change), and this is very limited in such a short sample (about half the size of the post-1984 estimation).

Countries arising from the disintegration of Yugoslavia and the Soviet Union have recently brought war back to Europe. Participants in these conflicts, such as Armenia, Croatia, Georgia, Russia and Yugoslavia, are classified as limited democracies (even using a narrow definition). The results suggest that the nineteenth and early twentieth centuries constitute a better model for the contemporary pattern of conflict than the Cold War period.

\section{Conclusion}

According to Paine and Kant, democracy is good for peace because wars are disadvantageous to the population at large. But if wars are caused by fear and distrust, then the link between democracy and peace is not obvious. In our simple model of Schelling's dilemma, the average citizen wants peace, but he is not a dominant strategy dove, so he supports aggressive actions against enemies he perceives as hostile. The model suggests a possibly non-monotonic relationship between democracy and peace, which is in fact found in the data. Our empirical analysis of militarized disputes in the nineteenth and twentieth centuries reveals that dyads consisting of two limited democracies are the most conflict-ridden of all dyads (including "mixed" dyads). Dyads consisting of two full democracies are peaceful, but as the environment becomes more hostile, full democracies become more aggressive faster than other regime types. These empirical findings are consistent with the simple model.

A non-monotonic relationship between democracy and peace has important policy implications. Many countries in the Middle East are classified as dictatorships, or vacillate between dictatorship and limited democracy. For example, between 1981 and 2000, Afghanistan, Iraq, Kuwait, Libya, Saudi Arabia and Syria are classified as dictatorships in our baseline model. ${ }^{33}$ Algeria, Egypt, Jordan, Iran and Tunisia are either dictatorships or limited democracies at different times. According to President George W. Bush [16], "the advance of freedom leads to peace." Unfortunately, the data suggests that this may not be true for a limited advance of freedom.

\footnotetext{
${ }^{32}$ Consistent with these results, Gowa [35] estimates a pooled logit model after the Cold War and finds weak support for the democratic peace hypothesis.

${ }^{33}$ Morocco, Oman, Qatar and United Arab Emirates are also classified as dictatorships.
} 


\section{A Appendix: Proof of Proposition 3}

Let $p_{T T^{\prime}}$ denote the equilibrium probability that regime type $T \in\{D e, D i, L i\}$ chooses $A$ when playing against regime type $T^{\prime} \in\{D e, D i, L i\}$. By definition of equilibrium, $h\left(p_{T^{\prime} T}, T\right)=p_{T T^{\prime}}$. The arguments used to prove Propositions 1 and 2 show that $p_{D e D e}<p_{D e T}<p_{T D e}$ and $w_{D e D e}<w_{T D e}$ for $T \in\{D i, L i\}$. Now consider two cases.

Case 1: suppose country $j$ changes from a full democracy to a dictatorship. Notice that $h(p, D i)-h(p, D e)$ is decreasing in $p$. Since $p_{D e D e}<p_{T D e}$ for $T \in\{D i, L i\}$,

$$
h\left(p_{D e D e}, D i\right)-h\left(p_{D e D e}, D e\right)>h\left(p_{T D e}, D i\right)-h\left(p_{T D e}, D e\right)
$$

or

$$
h\left(p_{D e D e}, D i\right)-p_{D e D e}>h\left(p_{T D e}, D i\right)-p_{D e T} .
$$

By definition,

$$
p_{D e D e}+\left(1-p_{D e D e}\right) p_{D e D e}-w_{D e D e}=p_{T D e}+\left(1-p_{T D e}\right) p_{D e T}-w_{T D e}=0
$$

Hence, by (14) and as $1-p_{D e D e}>1-p_{T D e}$, we have

$$
p_{D e D e}+\left(1-p_{D e D e}\right) h\left(p_{D e D e}, D i\right)-w_{D e D e}>p_{T D e}+\left(1-p_{T D e}\right) h\left(p_{T D e}, D i\right)-w_{T D e}
$$

By (5) and (9), if $p_{j}<\frac{1}{2}, \frac{\partial h\left(p_{j}, D e\right)}{\partial p_{j}}>\frac{\partial h\left(p_{j}, D i\right)}{\partial p_{j}}$. Also, recall $h(p, T)$ for $T \in\{D i, L i\}$ is increasing and strictly concave, and $p_{T D e}>p_{D e D e}$ implies $h\left(p_{T D e}, D i\right)>h\left(p_{D e D e}, D i\right)$. Hence, we must have

$$
\left.\frac{\partial h\left(p_{j}, D e\right)}{\partial p_{j}}\right|_{p_{j}=h\left(p_{D e D e}, D i\right)}>\left.\frac{\partial h\left(p_{j}, D i\right)}{\partial p_{j}}\right|_{p_{j}=h\left(p_{D e D e}, D i\right)}>\left.\frac{\partial h\left(p_{j}, D i\right)}{\partial p_{j}}\right|_{p_{j}=h\left(p_{T D e}, D i\right)}>0
$$

These inequalities, the fact that $1-h\left(p_{T D e}, D i\right)<1-h\left(p_{D e D e}, D i\right)$, and $(15)$ imply

$$
\begin{gathered}
h\left(h\left(p_{D e D e}, D i\right), D e\right)+\left(1-h\left(h\left(p_{D e D e}, D i\right), D e\right)\right) h\left(p_{D e D e}, D i\right)-w_{D e D e} \\
>h\left(h\left(p_{T D e}, D i\right), T\right)+\left(1-h\left(h\left(p_{T D e}, D i\right), T\right)\right) h\left(p_{T D e}, D i\right)-w_{T D e} .
\end{gathered}
$$

We can repeat this process until equilibrium is reached, with the inequality satisfied at each step. Figure 3 illustrates that we must then have

$$
w_{D e D i}-w_{D e D e}>w_{T D i}-w_{T D e} \text { for } T \in\{D i, L i\} .
$$

Case 2: suppose country $j$ changes from a full democracy to a limited democracy. Notice that $h(p, L i)-h(p, D e)$ is decreasing in $p$. Hence, for all $p_{D e D e}<1$, we have $h\left(p_{D e D e}, L i\right)-$ $h\left(p_{D e D e}, D e\right)>h\left(p_{T D e}, L i\right)-h\left(p_{T D e}, D e\right)$ as $p_{D e D e}<p_{T D e}$ for $T \in\{D i, L i\}$. Also, by (7) and (9), 
$\frac{\partial h\left(p_{j}, D e\right)}{\partial p_{j}}>\frac{\partial h\left(p_{j}, L i\right)}{\partial p_{j}}$. Proceeding as in the first case then implies that $w_{D e L i}-w_{D e D e}>w_{T L i}-w_{T D e}$ for $T \in\{D i, L i\}$.

This completes the proof of Proposition 3. 


\section{References}

[1] Acemoglu, D. and J. Robinson (2006), Economic Origins of Dictatorship and Democracy, Cambridge University Press, Cambridge.

[2] Albert, A. and J. A. Anderson, "On the existence of maximum likelihood estimates in logistic regression models," Biometrika, 71(1), 1:10

[3] Asprey, R. B. (1991): The German High Command at War: Hindenburg and Ludendorff conduct World War I, Wiley, New York.

[4] Axelrod, Robert (1984): The Evolution of Cooperation, New York: Basic Books.

[5] Babst, D. (1972): “A Force for Peace," Industrial Research 14:55-58.

[6] Baliga, S. and T. Sjöström (2004): "Arms Races and Negotiations," Review of Economic Studies, 71:351-369

[7] Barbieri, K. (1996) Economic Interdependence and Militarized Interstate Conflict, 1870-1985, Ph.D. Dissertation. Binghamton University, Binghamton, NY.

[8] Barro, R. (1973): "The Control of Politicians: An Economic Model," Public Choice, 14: 19-42.

[9] Beck N., Katz J., and Tucker R.(1997): "Taking Time Seriously: Time-Series- Cross-Section Analysis with Binary Dependent Variable," American Journal of Political Science 41:846-878

[10] Bennett, S. (2006): "Towards a Continuous Specification of the Democracy-Autocracy Connection," International Studies Quarterly 50(2):313-338.

[11] Bobbitt, P. (2008): Terror and Consent. Knopf: New York.

[12] Bueno de Mesquita B., and R. M. Silverson (1995): "War and the Survival of Political Leaders: A Comparative Study of Regime Types and Political Accountability," American Political Science Review 89:841-855.

[13] Bueno de Mesquita B., J. D. Morrow, R. M. Silverson and A. Smith (1999): "An Institutional Explanation of the Democratic Peace," American Political Science Review 93:791-807.

[14] Beck, N, Katz J. N. and Tucker R.(1998): "Taking Time Seriously: Time-Series-Cross-Section Analysis with a Binary Dependent Variable," American Journal of Political Science, 42(4): $1260-1288$

[15] Bremer, S. (1992): "Dangerous Dyads," Journal of Conflict Resolution 36 (2): 309-4

[16] Bush, G. W. (2003): "Remarks by the President at the 20th Anniversary of the National Endowment for Democracy," United States Chamber of Commerce, Washington, D.C. (http://www.whitehouse.gov/news/releases/2003/11/20031106-2.html) 
[17] Hans Carlsson and Eric van Damme (1993): "Global Games and Equilibrium Selection," Econometrica, 989-1018.

[18] Chamberlain, G. (1980): "Analysis of Covariance with Qualitative Data," Review of Economic Studies 47, 225-238.

[19] Sylvain Chassang and Gerard Padro-i-Miguel (2008): "Conflict and Deterrence under Strategic Risk," mimeo, Princeton.

[20] Sylvain Chassang and Gerard Padro-i-Miguel (2009): "Economic Shocks and Civil War," mimeo, Princeton.

[21] Craig, G. (1978): Germany 1866-1945, Oxford University Press, Oxford.

[22] Downs, G. and D. M. Rocke (1994): "Conflict, Agency and Gambling for Resurrection: The Principal-Agent Model Goes to War," American Journal of Political Science, 38: 362-80.

[23] Epstein D., Bates R., Goldstone J., Kristensen I. and O'Halloran S. (2006): "Democratic transitions," American Journal of Political Science, 50(3): 551-569.

[24] Farber H., and Gowa J. (1997): "Common Interests or Common Polities? Reinterpreting the Democratic Peace," Journal of Politics, 59(2): 393-417

[25] Fearon, J. (1994): "Domestic Political Audiences and the Escalation of International Disputes," American Political Science Review 88: 577-592.

[26] Fearon, J. (1995): "Rationalist Explanations for War," International Organization, 49 (3), pp 379-414.

[27] Fearon, J. (1996): "Bargaining over Objects that Influence Future Bargaining," mimeo, Stanford

[28] Fearon, J. and Laitin D. (2003): "Ethnicity, insurgency, and civil war," American Political Science Review, 97(1), pp 75-90.

[29] Ferejohn, J. (1986): "Incumbent Performance and Electoral Control," Public Choice, 50, 5-25.

[30] Freedom House (2006). Freedom House Country Ratings, available at www.Freedomhouse.org

[31] Frost, J. (1882): The History of Mexico and its Wars, Armand Hawkins, New Orleans.

[32] Gaddis J. (2005): The Cold War: A New History, Penguin Books, London.

[33] Goemans, H. (2000): "Fighting for Survival: The Fate of Leaders and the Duration of War," Journal of Conflict Resolution 44: 555-579.

[34] Goldberg J. (2005): "Breaking Ranks," in Letter from Washington, New Yorker, Oct. 31, 2005. 
[35] Gowa J. (2008): "The Democratic Peace after the Cold War," unpublished paper

[36] Gurr, T. (1974): "Persistence and Change in Political Systems, 1800-1971," American Political Science Review, 68: 1482-1504.

[37] Hess, G. and A. Orphanides (1995): "War Politics: An Economic, Rational-Voter Framework," American Economic Review, 85: 828-846.

[38] Hopkirk, P. (1990): The Great Game: On Secret Service in High Asia, John Murray Ltd., London.

[39] Howarth, T. E. B. (1961): Citizen-King: The Life of Louis-Philippe, King of the French, Eyre and Spottiswoode, London.

[40] Jackson, M. and M. Morelli (2005): "Political Bias and War," mimeo, Caltech and OSU.

[41] Jervis, R. (1976) Perception and Misperception in International Politics (Princeton: Princeton University Press).

[42] Jervis, R. (1978) "Cooperation under the Security Dilemma", World Politics 30, 167-214.

[43] Jones,D., Bremer S., and Singer D. (1996): "Militarized Interstate Disputes, 1816-1992: Rationale, Coding Rules, and Empirical Patters," Conflict Management and Peace Science 15(2); $163: 213$

[44] Kaplan, L. and W. Kristol (2003): The War Over Iraq: Saddam's Tyranny and America's Mission, Encounter Books.

[45] Kant, Immanuel (1795): "Perpetual Peace: A Philosophical Sketch"

[46] Kydd, A. (1997), "Game Theory and the Spiral Model", World Politics, 49, 371-400.

[47] Leeds, Brett A. (1999): "Domestic Political Institutions, Credible Commitments, and International Cooperation," American Journal of Political Science, Vol. 43, No. 4, pp. 979-1002

[48] Leffler, M. (1992) A Preponderance of Power: National Security, the Truman Administration and the Cold War. Stanford: Stanford University Press.

[49] Levy, J. (1988): "Domestic Politics and War," Journal of Interdisciplinary History 18:653-673.

[50] Levy, G. and R. Razin (2004): "It takes Two: An Explanation for the Democratic Peace," Journal of the European economic Association 2:1-29.

[51] Mansfield, E. and J. Snyder (2005): Electing to Fight: Why Emerging Democracies go to War, M.I.T. Press, Cambridge, MA.

[52] Maoz, Z. 1999. "Dyadic Militarized Interstate Disputes, version 1.1." Available at http:// spirit.tau.ac.il/poli/faculty/maoz/dyadmid.html 
[53] Maoz, Z., and B. Russett (1993): "Normative and Structural Causes of Democratic Peace, 1946-1986," American Political Science Review 87:624-638.

[54] Marshall, Monty G. and Keith Jaggers. 2002. Polity IV Project: Political Regime Characteristics and Transitions, 1800-2002. http://www.cidcm.umd.edu/inscr/polity/index.htm.

[55] Nye, Joseph S. (2007): Understanding International Conflict, Longman Classics in Political Science, New York

[56] Oneal, J. and B. Russett (1997): "The Classical Liberals were Right: Democracy, Interdependence and Conflict, 1950-1985," International Studies Quarterly 41:267-294.

[57] Paine, T. (1985): Rights of Man, Viking Penguin Inc.

[58] Peceny, Mark, Caroline Beer and Shannon Sanchez-Terry (2004): "Dictatorial Peace?," American Political Science Review 96(1):15-26.

[59] Powell, Robert (2006): "War as a Commitment Problem," International Organization (Winter 2006).

[60] Reiter, Dan. (1995): "Exploding the Powder Keg Myth: Preemptive Wars Almost Never Happen," International Security 20:5-34.

[61] Reiter, Dan. 2000. "Interstate Alliances, 1985-1992: version 2." mimeo, Emory University.

[62] Russett, B. and J. Oneal (2001): Triangulating Peace, W.W. Norton and Company, New York City.

[63] Schelling, T. (1960): Strategy of Conflict, Harvard University Press, Cambridge, MA.

[64] Simmons, B. (1999): "Territorial Disputes and their Resolution: The Case of Ecuador and Peru," United States Institute of Peace, Peaceworks No. 27.

[65] Snyder, Glenn H. (1971): “'Prisoner's dilemma' and 'Chicken' models in international politics," International Studies Quarterly.

[66] Snyder, Glenn H. and Paul Diesing (1977): Conflict among nations: bargaining, decision making, and system structure in international crises, Princeton University Press, Princeton, NJ.

[67] Sontag, R. (1933). European Diplomatic History, 1871-1932. New York: Appleton-CenturyCrofts.

[68] Tangeras, T. (2008): "Democracy, Autocracy and the Likelihood of International Conflict," mimeo, Stockholm

[69] Thorne, R. G. (1986). The House of Commons: 1790-1820. London: Secker and Warburg. 
[70] Thucydides (1972). The History of the Peloponnesian War, Penguin Classics, London.

[71] Ticchi, D. and Vindigni, A. (2006) "On Wars and Political Development: The Role of International Conflicts in the Democratization of the West," mimeo, UC Berkeley

[72] Tuchman, B. (1962): The Guns of August, Random House, New York, NY.

[73] Van Evera, S. (1999): The Causes of War, Cornell University Press, Ithaca, NY.

[74] Vives, Xavier (2001): Oligopoly Pricing, MIT Press, Cambridge, MA.

[75] Wainstein, Leonard (1971), "The Dreadnought Gap," in Robert Art and Kenneth Waltz, eds., The Use of Force. Boston: Little Brown.

[76] Wetzel, D. (2001): A Duel of Giants: Bismarck, Napoleon III, and the Origins of the FrancoPrussian War. University of Wisconsin Press, Madison.

[77] Wooldridge, J.M. (2002): Econometric Analysis of Cross Section and Panel Data, M.I.T. Press, Cambridge, MA

[78] Xue, J. (2006): "Collective Action with Endogenous Thresholds," Cambridge Working Paper 0613, Cambridge University 
Table 1: Sample of limited democracies

\begin{tabular}{|c|c|c|c|c|}
\hline COW code & Country & N. of years & First year & Last year \\
\hline 501 & Kenya & 10 & 1963 & 2000 \\
\hline 345 & Yugoslavia & 10 & 1921 & 1940 \\
\hline 703 & Kyrgyzstan & 10 & 1991 & 2000 \\
\hline 850 & Indonesia & 10 & 1949 & 1958 \\
\hline 640 & Turkey & 11 & 1909 & 1972 \\
\hline 452 & Ghana & 11 & 1970 & 2000 \\
\hline 732 & South Korea & 12 & 1949 & 1971 \\
\hline 350 & Greece & 13 & 1833 & 1924 \\
\hline 551 & Zambia & 13 & 1964 & 2000 \\
\hline 663 & Jordan & 14 & 1952 & 2000 \\
\hline 110 & Guyana & 14 & 1966 & 1979 \\
\hline 630 & Iran & 16 & 1941 & 2000 \\
\hline 355 & Bulgaria & 16 & 1918 & 1933 \\
\hline 220 & France & 17 & 1830 & 1869 \\
\hline 730 & Korea & 17 & 1887 & 1904 \\
\hline 230 & Spain & 18 & 1837 & 1878 \\
\hline 817 & Republic of Vietnam & 20 & 1955 & 1974 \\
\hline 325 & Italy & 22 & 1900 & 1921 \\
\hline 235 & Portugal & 23 & 1823 & 1909 \\
\hline 651 & Egypt & 24 & 1937 & 1998 \\
\hline 433 & Senegal & 24 & 1960 & 1999 \\
\hline 660 & Lebanon & 24 & 1946 & 1969 \\
\hline 310 & Hungary & 25 & 1920 & 1988 \\
\hline 255 & Germany & 27 & 1890 & 1917 \\
\hline 790 & Nepal & 28 & 1920 & 1989 \\
\hline 93 & Nicaragua & 31 & 1909 & 1989 \\
\hline 101 & Venezuela & 34 & 1892 & 1957 \\
\hline 95 & Panama & 35 & 1920 & 1954 \\
\hline 800 & Thailand & 36 & 1935 & 1991 \\
\hline 830 & Singapore & 36 & 1965 & 2000 \\
\hline 42 & Dominican Republic & 37 & 1894 & 1977 \\
\hline 150 & Paraguay & 39 & 1876 & 1991 \\
\hline 100 & Colombia & 43 & 1832 & 1903 \\
\hline 92 & El Salvador & 44 & 1875 & 1976 \\
\hline 140 & Brazil & 44 & 1889 & 1984 \\
\hline 91 & Honduras & 47 & 1904 & 1979 \\
\hline 40 & Cuba & 47 & 1902 & 1951 \\
\hline 390 & Denmark & 50 & 1849 & 1900 \\
\hline 200 & United Kingdom & 58 & 1816 & 1879 \\
\hline 70 & Mexico & 59 & 1831 & 1993 \\
\hline 90 & Guatemala & 62 & 1868 & 1995 \\
\hline 210 & Netherlands & 66 & 1849 & 1916 \\
\hline 41 & Haiti & 67 & 1859 & 2000 \\
\hline 165 & Uruguay & 69 & 1882 & 1951 \\
\hline 740 & Japan & 76 & 1868 & 1944 \\
\hline 145 & Bolivia & 82 & 1848 & 1963 \\
\hline 160 & Argentina & 84 & 1853 & 1965 \\
\hline 135 & Peru & 99 & 1839 & 1999 \\
\hline 155 & Chile & 99 & 1851 & 1988 \\
\hline 130 & Ecuador & 114 & 1854 & 1971 \\
\hline
\end{tabular}

Notes: The Table shows the list of countries included in the estimation of the baseline regression model ( 1 in Table 6 ) that are classified as limited democracies for the longest period of time. A political regime is defined as a limited democracy when the value of the Polity IV net democracy score lies in the interval $[-3,3]$. The second-to-last column shows the first year in which the political regime of the country is classified as a limited democracy, and the last column reports the most recent year. 
Table 2: Militarized disputes for a sample of limited democracies

\begin{tabular}{|c|c|c|c|c|c|c|}
\hline COW code & Country & Freq. of MIDs & N. of MIDs & N. of years & First year & Last year \\
\hline 91 & Honduras & $15 \%$ & 7 & 47 & 1904 & 1979 \\
\hline 42 & Dominican Republic & $16 \%$ & 6 & 37 & 1894 & 1977 \\
\hline 433 & Senegal & $17 \%$ & 4 & 24 & 1960 & 1999 \\
\hline 730 & Korea & $18 \%$ & 3 & 17 & 1887 & 1904 \\
\hline 452 & Ghana & $18 \%$ & 2 & 11 & 1970 & 2000 \\
\hline 645 & Iraq & $20 \%$ & 1 & 5 & 1936 & 1940 \\
\hline 483 & Chad & $20 \%$ & 1 & 5 & 1996 & 2000 \\
\hline 703 & Kyrgyzstan & $20 \%$ & 2 & 10 & 1991 & 2000 \\
\hline 140 & Brazil & $20 \%$ & 9 & 44 & 1889 & 1984 \\
\hline 101 & Venezuela & $21 \%$ & 7 & 34 & 1892 & 1957 \\
\hline 663 & Jordan & $21 \%$ & 3 & 14 & 1952 & 2000 \\
\hline 70 & Mexico & $22 \%$ & 13 & 59 & 1831 & 1993 \\
\hline 230 & Spain & $22 \%$ & 4 & 18 & 1837 & 1878 \\
\hline 350 & Greece & $23 \%$ & 3 & 13 & 1833 & 1924 \\
\hline 41 & Haiti & $24 \%$ & 16 & 67 & 1859 & 2000 \\
\hline 130 & Ecuador & $25 \%$ & 28 & 114 & 1854 & 1971 \\
\hline 540 & Angola & $25 \%$ & 1 & 4 & 1997 & 2000 \\
\hline 702 & Tajikistan & $25 \%$ & 1 & 4 & 1991 & 2000 \\
\hline 552 & Zimbabwe & $25 \%$ & 1 & 4 & 1983 & 1986 \\
\hline 660 & Lebanon & $25 \%$ & 6 & 24 & 1946 & 1969 \\
\hline 145 & Bolivia & $27 \%$ & 22 & 82 & 1848 & 1963 \\
\hline 155 & Chile & $27 \%$ & 27 & 99 & 1851 & 1988 \\
\hline 310 & Hungary & $28 \%$ & 7 & 25 & 1920 & 1988 \\
\hline 110 & Guyana & $29 \%$ & 4 & 14 & 1966 & 1979 \\
\hline 850 & Indonesia & $30 \%$ & 3 & 10 & 1949 & 1958 \\
\hline 501 & Kenya & $30 \%$ & 3 & 10 & 1963 & 2000 \\
\hline 100 & Colombia & $30 \%$ & 13 & 43 & 1832 & 1903 \\
\hline 93 & Nicaragua & $32 \%$ & 10 & 31 & 1909 & 1989 \\
\hline 510 & Tanzania & $33 \%$ & 2 & 6 & 1995 & 2000 \\
\hline 516 & Burundi & $33 \%$ & 2 & 6 & 1962 & 2000 \\
\hline 678 & Yemen Arab Republic & $33 \%$ & 3 & 9 & 1963 & 1973 \\
\hline 160 & Argentina & $33 \%$ & 28 & 84 & 1853 & 1965 \\
\hline 135 & Peru & $34 \%$ & 34 & 99 & 1839 & 1999 \\
\hline 150 & Paraguay & $36 \%$ & 14 & 39 & 1876 & 1991 \\
\hline 325 & Italy & $36 \%$ & 8 & 22 & 1900 & 1921 \\
\hline 355 & Bulgaria & $38 \%$ & 6 & 16 & 1918 & 1933 \\
\hline 551 & Zambia & $38 \%$ & 5 & 13 & 1964 & 2000 \\
\hline 713 & Taiwan & $40 \%$ & 2 & 5 & 1987 & 1991 \\
\hline 434 & Benin & $40 \%$ & 2 & 5 & 1960 & 1971 \\
\hline 345 & Yugoslavia & $40 \%$ & 4 & 10 & 1921 & 1940 \\
\hline 732 & South Korea & $42 \%$ & 5 & 12 & 1949 & 1971 \\
\hline 811 & Cambodia & $43 \%$ & 3 & 7 & 1993 & 2000 \\
\hline 200 & United Kingdom & $43 \%$ & 25 & 58 & 1816 & 1879 \\
\hline 255 & Germany & $44 \%$ & 12 & 27 & 1890 & 1917 \\
\hline 740 & Japan & $49 \%$ & 37 & 76 & 1868 & 1944 \\
\hline 373 & Azerbaijan & $50 \%$ & 2 & 4 & 1991 & 1994 \\
\hline 530 & Ethiopia & $50 \%$ & 3 & 6 & 1995 & 2000 \\
\hline 679 & Yemen & $50 \%$ & 4 & 8 & 1993 & 2000 \\
\hline 630 & Iran & $50 \%$ & 8 & 16 & 1941 & 2000 \\
\hline 651 & Egypt & $54 \%$ & 13 & 24 & 1937 & 1998 \\
\hline 640 & Turkey & $55 \%$ & 6 & 11 & 1909 & 1972 \\
\hline 800 & Thailand & $56 \%$ & 20 & 36 & 1935 & 1991 \\
\hline 220 & France & $59 \%$ & 10 & 17 & 1830 & 1869 \\
\hline 817 & Republic of Vietnam & $60 \%$ & 12 & 20 & 1955 & 1974 \\
\hline 770 & Pakistan & $63 \%$ & 5 & 8 & 1948 & 1968 \\
\hline 652 & Syria & $67 \%$ & 2 & 3 & 1950 & 1962 \\
\hline 344 & Croatia & $67 \%$ & 2 & 3 & 1992 & 1994 \\
\hline 438 & Guinea & $67 \%$ & 4 & 6 & 1995 & 2000 \\
\hline 365 & Russia & $71 \%$ & 5 & 7 & 1917 & 1991 \\
\hline 450 & Liberia & $75 \%$ & 3 & 4 & 1997 & 2000 \\
\hline 339 & Albania & $75 \%$ & 3 & 4 & 1914 & 1996 \\
\hline 411 & Equatorial Guinea & $100 \%$ & 1 & 1 & 1968 & 1968 \\
\hline
\end{tabular}

Notes: The Table shows the list of countries included in the estimation of the baseline regression model

(1 in Table 6) that are classified as limited democracies and were most frequently involved in militarized disputes. See the footnote to Table 1 for a definition of a limited democracy, and details about the last three columns. The "N. of MIDs" column reports the number of years in which a country is involved in a militarized dispute while the regime is classified as a limited democracy. The column "Freq. of MIDs" reports the ratio of "N. of MIDs" to "N. of years." 
Table 3: Militarized disputes for a sample of dyads of limited democracies

\begin{tabular}{|c|c|c|c|c|c|c|c|c|}
\hline COW code & Country & COW code & Country & Freq. of MIDs & N. of MIDs & N. of years & First Year & Last Year \\
\hline 255 & Germany & 740 & Japan & $5 \%$ & 1 & 22 & 1890 & 1912 \\
\hline 101 & Venezuela & 740 & Japan & $5 \%$ & 1 & 21 & 1892 & 1944 \\
\hline 140 & Brazil & 145 & Bolivia & $5 \%$ & 2 & 40 & 1889 & 1963 \\
\hline 135 & Peru & 145 & Bolivia & $5 \%$ & 3 & 57 & 1848 & 1935 \\
\hline 135 & Peru & 155 & Chile & $5 \%$ & 4 & 74 & 1852 & 1949 \\
\hline 100 & Colombia & 135 & Peru & $6 \%$ & 2 & 36 & 1839 & 1903 \\
\hline 730 & Korea & 740 & Japan & $6 \%$ & 1 & 17 & 1887 & 1904 \\
\hline 101 & Venezuela & 210 & Netherlands & $6 \%$ & 1 & 17 & 1892 & 1908 \\
\hline 135 & Peru & 230 & Spain & $7 \%$ & 1 & 15 & 1839 & 1878 \\
\hline 200 & United Kingdom & 235 & Portugal & $7 \%$ & 1 & 14 & 1823 & 1841 \\
\hline 100 & Colombia & 220 & France & $7 \%$ & 1 & 14 & 1832 & 1847 \\
\hline 135 & Peru & 140 & Brazil & $7 \%$ & 2 & 27 & 1889 & 1918 \\
\hline 140 & Brazil & 150 & Paraguay & $8 \%$ & 2 & 26 & 1904 & 1929 \\
\hline 160 & Argentina & 255 & Germany & $8 \%$ & 2 & 26 & 1890 & 1917 \\
\hline 145 & Bolivia & 155 & Chile & $8 \%$ & 5 & 63 & 1851 & 1935 \\
\hline 40 & Cuba & 255 & Germany & $8 \%$ & 1 & 12 & 1902 & 1916 \\
\hline 91 & Honduras & 740 & Japan & $9 \%$ & 1 & 11 & 1904 & 1944 \\
\hline 70 & Mexico & 220 & France & $9 \%$ & 1 & 11 & 1831 & 1845 \\
\hline 41 & Haiti & 42 & Dominican Republic & $10 \%$ & 2 & 20 & 1894 & 1913 \\
\hline 93 & Nicaragua & 255 & Germany & $11 \%$ & 1 & 9 & 1909 & 1917 \\
\hline 150 & Paraguay & 160 & Argentina & $11 \%$ & 3 & 27 & 1876 & 1929 \\
\hline 91 & Honduras & 92 & El Salvador & $12 \%$ & 2 & 17 & 1960 & 1976 \\
\hline 200 & United Kingdom & 220 & France & $12 \%$ & 2 & 17 & 1830 & 1869 \\
\hline 100 & Colombia & 200 & United Kingdom & $12 \%$ & 3 & 25 & 1832 & 1859 \\
\hline 310 & Hung ary & 345 & Yugoslavia & $13 \%$ & 1 & 8 & 1921 & 1939 \\
\hline 220 & France & 235 & Portugal & $13 \%$ & 1 & 8 & 1830 & 1841 \\
\hline 651 & Egypt & 740 & Japan & $13 \%$ & 1 & 8 & 1937 & 1944 \\
\hline 452 & Ghana & 461 & Togo & $13 \%$ & 1 & 8 & 1993 & 2000 \\
\hline 90 & Guatemala & 92 & El Salvador & $13 \%$ & 4 & 32 & 1875 & 1976 \\
\hline 41 & Haiti & 255 & Germany & $13 \%$ & 3 & 23 & 1890 & 1914 \\
\hline 155 & Chile & 160 & Argentina & $13 \%$ & 9 & 68 & 1853 & 1929 \\
\hline 100 & Colombia & 101 & Venezuela & $18 \%$ & 2 & 11 & 1892 & 1903 \\
\hline 740 & Japan & 800 & Thailand & $22 \%$ & 2 & 9 & 1935 & 1944 \\
\hline 130 & Ecuador & 135 & Peru & $24 \%$ & 15 & 62 & 1854 & 1949 \\
\hline 230 & Spain & 235 & Portugal & $25 \%$ & 1 & 4 & 1837 & 1841 \\
\hline 630 & Iran & 740 & Japan & $25 \%$ & 1 & 4 & 1941 & 1944 \\
\hline 540 & Angola & 551 & Zambia & $25 \%$ & 1 & 4 & 1997 & 2000 \\
\hline 501 & Kenya & 530 & Ethiopia & $25 \%$ & 1 & 4 & 1997 & 2000 \\
\hline 345 & Yugoslavia & 355 & Bulgaria & $25 \%$ & 2 & 8 & 1921 & 1928 \\
\hline 350 & Greece & 355 & Bulgaria & $33 \%$ & 1 & 3 & 1920 & 1924 \\
\hline 652 & Syria & 660 & Lebanon & $33 \%$ & 1 & 3 & 1950 & 1962 \\
\hline 510 & Tanzania & 516 & Burundi & $33 \%$ & 1 & 3 & 1998 & 2000 \\
\hline 325 & Italy & 640 & Turkey & $40 \%$ & 2 & 5 & 1909 & 1913 \\
\hline 145 & Bolivia & 150 & Paraguay & $41 \%$ & 11 & 27 & 1904 & 1935 \\
\hline 438 & Guinea & 450 & Liberia & $67 \%$ & 2 & 3 & 1997 & 1999 \\
\hline 255 & Germany & 365 & Russia & $100 \%$ & 1 & 1 & 1917 & 1917 \\
\hline 365 & Russia & 640 & Turkey & $100 \%$ & 1 & 1 & 1917 & 1917 \\
\hline
\end{tabular}

Notes: The Table shows the list of dyadic country pairs included in the estimation of the baseline regression model ( 1 in Table 6 ) that are classified as limited democracies and were most frequently involved in militarized disputes. A political regime is defined as a limited democracy when the value of the Polity IV net democracy index lies in the interval $[-3,3]$. The last three columns report, respectively, the number of years, first year and last year in which both regimes in the dyad are classified as limited democracies. The "N. of MIDs" and "Freq. of MIDs" columns show, respectively, the number of years in which the countries in the dyad were involved in a MID, and the fraction of years in conflict to those in which both countries are classified as limited democracies. 
Table 4: Definition of the regime type dummy variables

\begin{tabular}{lccc}
\hline & $\begin{array}{c}\text { Dictatorship } \\
\text { NetDem }_{2} \in[-10,-4]\end{array}$ & $\begin{array}{c}\text { Limited Democracy } \\
\text { NetDem }_{2} \in[-3,3]\end{array}$ & $\begin{array}{c}\text { Democracy } \\
\text { NetDem }_{2} \in[4,10]\end{array}$ \\
\hline $\begin{array}{l}\text { Dictatorship } \\
\text { NetDem }\end{array} \in[-10,-4]$ & $D_{D i D i}$ & $D_{L i D i}$ & $D_{D e D i}$ \\
$\begin{array}{l}\text { Limited Democracy } \\
\text { NetDem }\end{array} \in[-3,3]$ & $D_{L i D i}$ & $D_{L i L i}$ & $D_{D e L i}$ \\
$\begin{array}{l}\text { Democracy } \\
\text { NetDem }_{2} \in[4,10]\end{array}$ & $D_{D e D i}$ & $D_{D e L i}$ & $D_{D e D i}$ \\
\hline
\end{tabular}

Notes: The table shows the set of regime type dummy variables included in the regression models. Each dummy variable $D_{j}$ is equal to one when NetDem 1 and NetDem 2 assume values in the relevant intervals, and are equal to zero otherwise.

Table 5: Sample description for the Baseline Model

\begin{tabular}{lcccc}
\hline Variable & Mean & Std. Dev. & Min & Max \\
\hline MID onset & 0.05 & 0.21 & 0 & 1 \\
$D_{D i D i}$ & 0.21 & 0.40 & 0 & 1 \\
$D_{L i D i}$ & 0.13 & 0.34 & 0 & 1 \\
$D_{L i L i}$ & 0.06 & 0.24 & 0 & 1 \\
$D_{D e D i}$ & 0.31 & 0.46 & 0 & 1 \\
$D_{D e L i}$ & 0.12 & 0.32 & 0 & 1 \\
$D_{D e D e}$ & 0.17 & 0.38 & 0 & 1 \\
MajPower & 0.54 & 0.50 & 0 & 1 \\
LogCapRatio & 2.40 & 1.67 & 0 & 8.44 \\
Allianced & 0.20 & 0.40 & 0 & 1 \\
\hline
\end{tabular}

Obs.: 40,786

Notes: Summary measures for the dependent (MID onset) and explanatory variables included in the baseline regression model (1 in Table 6$)$. 
Table 6: Regression models-Baseline

Dependent Variable: Onset of a Militarized Interstate Dispute

\begin{tabular}{|c|c|c|c|c|c|c|c|c|}
\hline Model & \multicolumn{2}{|c|}{ (1) BASELINE } & \multicolumn{2}{|c|}{$(2)$} & \multicolumn{2}{|c|}{$(3)$} & \multicolumn{2}{|c|}{ (4) } \\
\hline$D_{D i D i}$ & $\begin{array}{l}-0.58 \\
{[0.21]^{* * *}}\end{array}$ & $(<0.01)^{* * *}$ & $\begin{array}{l}-0.0027 \\
{[0.0013]^{* *}}\end{array}$ & $(<0.01)^{* * *}$ & $\begin{array}{l}-0.90 \\
{[0.18]^{* * *}}\end{array}$ & $(0.03)^{* *}$ & $\begin{array}{l}-0.35 \\
{[0.16]^{* *}}\end{array}$ & $(<0.01)^{* * *}$ \\
\hline$D_{L i D i}$ & $\begin{array}{l}-0.54 \\
{[0.20]^{* * *}}\end{array}$ & $(<0.01)^{* * *}$ & $\begin{array}{l}-0.0030 \\
{[0.0013]^{* *}}\end{array}$ & $(<0.01)^{* * *}$ & $\begin{array}{l}-0.47 \\
{[0.19]^{* *}}\end{array}$ & $(<0.01)^{* * *}$ & $\begin{array}{l}-0.26 \\
{[0.13]^{* *}}\end{array}$ & $(<0.01)^{* * *}$ \\
\hline$D_{D e D i}$ & $\begin{array}{l}-0.57 \\
{[0.20]^{* * *}}\end{array}$ & $(<0.01)^{* * *}$ & $\begin{array}{l}-0.0033 \\
{[0.0013]^{* *}}\end{array}$ & $(<0.01)^{* * *}$ & $\begin{array}{l}-0.34 \\
{[0.19]^{*}}\end{array}$ & $(<0.01)^{* * *}$ & $\begin{array}{l}-0.40 \\
{[0.17]^{* *}}\end{array}$ & $(<0.01)^{* * *}$ \\
\hline$D_{D e L i}$ & $\begin{array}{l}-0.70 \\
{[0.21]^{* * *}}\end{array}$ & $(<0.01)^{* * *}$ & $\begin{array}{l}-0.0044 \\
{[0.0014]^{* * *}}\end{array}$ & $(<0.01)^{* * *}$ & $\begin{array}{l}-0.44 \\
{[0.20]^{* *}}\end{array}$ & $(<0.01)^{* * *}$ & $\begin{array}{l}-0.26 \\
{[0.15]^{*}}\end{array}$ & $(<0.01)^{* * *}$ \\
\hline$D_{D e D e}$ & $\begin{array}{l}-1.38 \\
{[0.22]^{* * *}}\end{array}$ & 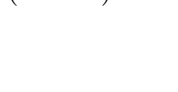 & {$[0.0014]^{* * *}$} & & $\begin{array}{l}-1.33 \\
{[0.23]^{* * *}}\end{array}$ & & $\begin{array}{l}-1.34 \\
{[0.25]^{* * *}}\end{array}$ & \\
\hline \multicolumn{9}{|l|}{ Panel b } \\
\hline Alliance & $\begin{array}{l}-0.38 \\
{[0.12]^{* * *}}\end{array}$ & & $\begin{array}{l}-0.0054 \\
{[0.0016]^{* * *}}\end{array}$ & & $\begin{array}{l}-0.06 \\
{[0.12]}\end{array}$ & & $\begin{array}{l}-0.41 \\
{[0.12]^{* * *}}\end{array}$ & \\
\hline MajPower & $\begin{array}{l}0.36 \\
{[0.28]}\end{array}$ & & $\begin{array}{l}0.0030 \\
{[0.0025]}\end{array}$ & & $\begin{array}{l}1.84 \\
{[0.15]^{* * *}}\end{array}$ & & $\begin{array}{l}0.42 \\
{[0.28]}\end{array}$ & \\
\hline LogCapRatio & $\begin{array}{l}-0.01 \\
{[0.07]}\end{array}$ & & $\begin{array}{l}0.0001 \\
{[0.0004]}\end{array}$ & & $\begin{array}{l}-0.13 \\
{[0.036]^{* * *}}\end{array}$ & & $\begin{array}{l}-0.01 \\
{[0.07]}\end{array}$ & \\
\hline Contig. & - & & - & & $\begin{array}{l}2.27 \\
{[0.15]^{* * *}}\end{array}$ & & - & \\
\hline LogDist & - & & - & & $\begin{array}{l}-0.36 \\
{[0.06]^{* * *}}\end{array}$ & & - & \\
\hline Model & CL & GIT & FE- & PM & & GIT & CLO & IT-Ds \\
\hline Years & 181 & -2000 & 1816 & 2000 & 181 & 2000 & 181 & -2000 \\
\hline Observations & & 786 & & 62 & & 420 & & 786 \\
\hline (pseudo) R2 & & 09 & & & & & & \\
\hline
\end{tabular}

Notes: * significant at $10 \%$; ** significant at $5 \%$; *** significant at $1 \%$. Robust standard errors reported in brackets below each coefficient. P-values for a Wald test of equality between each coefficient and the coefficient of $D_{D e D e}$ is reported in parenthesis next to the corresponding standard error. Models (1) and (4) are conditional logit models with fixed effects for each dyadic pair. Model (2) is a linear probability panel model with dyadic fixed effects. Model (3) is a pooled logit model. Standard errors are clustered at the directed dyadic level in model (2) and (3). Model (4) differs from (1) in the definition of the regime type dummy variables: In model (4), values of the Polity IV net democracy index in $[-6,6]$ are coded as limited democracies, values of $[-10,-7]$ as dictatorships and of $[7,10]$ as democracies. Each regression model includes (coefficient not reported) year fixed effects and cubic spline terms in the number of years since a country pair is last involved in a MID (see footnote 17 for additional detail.) 
Table 7: Partial effects for the pooled logit model (3 in Table 6)

\begin{tabular}{lcc}
\hline Variable & Partial Effect & \% Change \\
\hline$D_{D i D i}$ & $-0.001000^{* * *}$ & -59.1 \\
$D_{L i D i}$ & $-0.000635^{* *}$ & -37.5 \\
$D_{D e D i}$ & $-0.000489^{\wedge}$ & -28.9 \\
$D_{D e L i}$ & $-0.000607^{* *}$ & -35.9 \\
$D_{D e D e}$ & $-0.001243^{* * *}$ & -73.5 \\
\hline $\operatorname{Pr}(\mathrm{MID} \mid\{\mathrm{Li}, \mathrm{Li}\})=0.0017$ & & \\
\hline
\end{tabular}

Notes: $\operatorname{Pr}(\mathrm{MID} \mid\{\mathrm{Li}, \mathrm{Li}\})$ denotes the probability for a pair of limited democracies to engage in a militarized dispute, predicted by Model 3 in Table 6 when all $D_{j}$ 's are set to zero, and the other controls are equal to the respective sample means. The reported partial effects indicate the discrete change in conflict probability when the value of the corresponding dummy variable $D_{j}$ goes from zero to one. The significance of a Wald test for the null that each effect is zero is reported next to the corresponding estimate as:ŝignificant at $11 \%$; ** significant at $5 \%$; ** significant at $1 \%$.

Table 8: Test of Proposition 3

\begin{tabular}{lll}
\hline Regime Types & Value of $\left(\omega_{D e T^{\prime}}-\omega_{D e D e}\right)-\left(\omega_{T T^{\prime}}-\omega_{T D e}\right)$ \\
\hline$\left(\mathrm{T}=\mathrm{Di}, \mathrm{T}^{\prime}=\mathrm{Di}\right)$ & $0.003351^{* * *}$ & $0.001265^{* * *}$ \\
$\left(\mathrm{~T}=\mathrm{Li}, \mathrm{T}^{\prime}=\mathrm{Di}\right)$ & $0.0025678^{* * *}$ & $0.000783^{* * *}$ \\
$\left(\mathrm{~T}=\mathrm{Li}, \mathrm{T}^{\prime}=\mathrm{Li}\right)$ & -0.00163 & $0.001722^{* * *}$ \\
& & \\
\hline Specification & FE-LPM & LOGIT \\
\hline
\end{tabular}

Notes: The Table reports estimates of the conditional probabilities for each pair of regime types $T$ and $T^{\prime}$ that form (12), when the inequalities are expressed with all terms appearing on the left hand side. A positive number indicates that the corresponding inequality is satisfied. The parameters are estimated using the fixed effect linear probability model ( 2 in Table 6$)$, and the logit model ( 3 in Table 6 .) The significance of a Wald test for the null that each value is equal to zero is reported next to the point estimates: * significant at $10 \%$; ** significant at $5 \%$; *** significant at $1 \%$. Refer to footnote 25 for additional detail. 
Table 9: Regression models - comparison with Mansfield and Snyder [51]

Dependent Variable: Onset of a Militarized Interstate Dispute

\begin{tabular}{|c|c|c|c|c|c|c|}
\hline \multirow[b]{2}{*}{ Model } & \multicolumn{6}{|c|}{ Dependent Variable: Onset of a Militarized Interstate Dispute } \\
\hline & \multicolumn{2}{|c|}{$(1)$} & \multirow[t]{2}{*}{$(2)$} & \multicolumn{2}{|c|}{$(3)$} & \multirow[t]{2}{*}{$(4)$} \\
\hline Panel a & & & & & & \\
\hline$D_{D i D i}$ & $\begin{array}{l}-0.69 \\
{[0.26]^{* * *}}\end{array}$ & $(0.04)^{* *}$ & - & $\begin{array}{l}-0.22 \\
{[0.18]}\end{array}$ & $(<0.01)^{* * *}$ & - \\
\hline$D_{L i D i}$ & $\begin{array}{l}-0.48 \\
{[0.23]^{* *}}\end{array}$ & $(<0.01)^{* * *}$ & - & $\begin{array}{l}-0.37 \\
{[0.14]^{* * *}}\end{array}$ & $(<0.01)^{* * *}$ & - \\
\hline$D_{D e D i}$ & $\begin{array}{l}-0.58 \\
{[0.25]^{* *}}\end{array}$ & $(<0.01)^{* * *}$ & - & $\begin{array}{l}-0.31 \\
{[0.19]}\end{array}$ & $(<0.01)^{* * *}$ & - \\
\hline$D_{D e L i}$ & $\begin{array}{l}-0.62 \\
{[0.25]^{* *}}\end{array}$ & $(<0.01)^{* * *}$ & - & $\begin{array}{l}-0.13 \\
{[0.17]}\end{array}$ & $(<0.01)^{* * *}$ & - \\
\hline$D_{D e D e}$ & $\begin{array}{l}-1.14 \\
{[0.26]^{* * *}}\end{array}$ & & - & $\begin{array}{l}-0.98 \\
{[0.28]^{* * *}}\end{array}$ & & - \\
\hline \multicolumn{7}{|l|}{ Panel b } \\
\hline DiLi Trans. Dummy & $\begin{array}{l}-0.31 \\
{[0.16]^{*}}\end{array}$ & & $\begin{array}{l}-0.14 \\
{[0.14]}\end{array}$ & $\begin{array}{l}0.18 \\
{[0.11]^{*}}\end{array}$ & & $\begin{array}{l}0.29 \\
{[0.11]^{* * *}}\end{array}$ \\
\hline Alliance & $\begin{array}{l}-0.52 \\
{[0.13]^{* * *}}\end{array}$ & & $\begin{array}{l}-0.60 \\
{[0.13]^{* * *}}\end{array}$ & $\begin{array}{l}-0.59 \\
{[0.14]^{* * *}}\end{array}$ & & $\begin{array}{l}-0.61 \\
{[0.13]^{* * *}}\end{array}$ \\
\hline MajPower & $\begin{array}{l}0.26 \\
{[0.32]}\end{array}$ & & $\begin{array}{l}0.33 \\
{[0.31]}\end{array}$ & $\begin{array}{l}{[0.34]} \\
{[0.30]}\end{array}$ & & $\begin{array}{l}0.34 \\
{[0.31]}\end{array}$ \\
\hline LogCapRatio & $\begin{array}{l}0.03 \\
{[0.08]}\end{array}$ & & $\begin{array}{l}0.06 \\
{[0.08]}\end{array}$ & $\begin{array}{l}0.03 \\
{[0.08]}\end{array}$ & & $\begin{array}{l}0.06 \\
{[0.08]}\end{array}$ \\
\hline Model & $\mathrm{CL}$ & GIT & CLOGIT & $\mathrm{CL}$ & GIT & CLOGIT \\
\hline Years & 181 & -2000 & $1821-2000$ & 182 & -2000 & $1821-2000$ \\
\hline Observations & & 793 & 32793 & & 793 & 32793 \\
\hline (pseudo) R2 & & 08 & 0.09 & & .09 & 0.09 \\
\hline
\end{tabular}

Notes: $*$ significant at $10 \%$; ** significant at $5 \% ; * * *$ significant at $1 \%$. Robust standard errors reported in brackets below each coefficient. P-values for a Wald test for equality between each coefficient and the coefficient of $D_{D e D e}$ is reported in parenthesis next to the corresponding standard error. All models are conditional logit models with fixed effects for each dyadic pair. Models (3)-(4) differ from (1)-(2) in the definition of the dummy variables: values of the Polity IV net democracy index in $[-6,6]$ are coded as limited democracies, values in $[-10,-7]$ as dictatorships and in $[7,10]$ as democracies. The DiLi Trans Dummy is defined accordingly. At each date t, the dummy variable detects whether at least one of the countries' political system in a dyad transitioned from a dictatorship to a limited democracy between t-5 and t. Each regression model includes (coefficient not reported) year fixed effects and cubic spline terms in the number of years since a country pair is last involved in a MID (see footnote 17 for additional detail.) 
Table 10: Count of negative $D_{j}$ 's in baseline model (1 in Table 6) for alternative cutoff points in Polity scores.

\begin{tabular}{r|ccccc}
\hline \multirow{2}{*}{ Min } & \multicolumn{5}{|c}{ Max } \\
\cline { 2 - 6 } & 2 & 3 & 4 & 5 & 6 \\
-6 & $(5,5)$ & $(5,5)$ & $(5,5)$ & $(5,5)$ & $(5,5)$ \\
-5 & $(5,4)$ & $(5,4)$ & $(5,3)$ & $(5,2)$ & $(5,2)$ \\
-4 & $(5,5)$ & $(5,4)$ & $(5,3)$ & $(5,3)$ & $(5,2)$ \\
-3 & $(5,5)$ & $(\mathbf{5 , 5 )}$ & $(5,5)$ & $(5,5)$ & $(5,5)$ \\
-2 & $(5,5)$ & $(5,2)$ & $(5,2)$ & $(5,3)$ & $(5,2)$ \\
\hline
\end{tabular}

Notes: The table reports the number of point estimates of the regime type dummies $D_{j}$ that are negative as well as negative and significant at the $10 \%$ level - respectively, the first and second entry in each parenthesisunder alternative definitions of the regime type dummy variable in the baseline regression model ( 1 in Table 6). Limited democracies are defined for values of the Polity IV net democracy index between a minimum value reported in the first column and maximum value reported in the first row. The baseline model results, which are reported in full in column 1 of Table 6 , is shown in bold. 
Table 11: Regression models-Sub-samples

Dependent Variable: Onset of a Militarized Interstate Dispute

\begin{tabular}{|c|c|c|c|c|c|c|c|c|}
\hline \multirow[b]{2}{*}{ Model } & \multicolumn{8}{|c|}{ Dependent Variable: Onset of a Militarized Interstate Dispute } \\
\hline & \multicolumn{2}{|c|}{ (1) } & \multicolumn{2}{|r|}{$(2)$} & \multicolumn{2}{|c|}{$(3)$} & \multicolumn{2}{|c|}{$(4)$} \\
\hline Panel a & & & & & & & & \\
\hline$D_{D i D i}$ & $\begin{array}{l}-0.84 \\
{[0.26]^{* * *}}\end{array}$ & $(0.14)$ & $\begin{array}{l}-0.24 \\
{[0.38]}\end{array}$ & $(0.03)^{* *}$ & $\begin{array}{l}-1.63 \\
{[0.65]^{* *}}\end{array}$ & $(0.65)$ & $\begin{array}{l}0.14 \\
{[0.99]}\end{array}$ & $(0.11)$ \\
\hline$D_{L i D i}$ & $\begin{array}{l}-0.64 \\
{[0.22]^{* * *}}\end{array}$ & $(0.03)^{* *}$ & $\begin{array}{l}-0.47 \\
{[0.40]}\end{array}$ & $(0.35)$ & $\begin{array}{l}-1.46 \\
{[0.71]^{* *}}\end{array}$ & $(0.50)$ & $\begin{array}{l}-0.30 \\
{[0.91]}\end{array}$ & $(0.22)$ \\
\hline$D_{D e D i}$ & $\begin{array}{l}-0.62 \\
{[0.26]^{* *}}\end{array}$ & $(<0.01)^{* * *}$ & $\begin{array}{l}-0.25 \\
{[0.37]}\end{array}$ & $(<0.01)^{* * *}$ & $\begin{array}{l}-1.20 \\
{[0.68]^{*}}\end{array}$ & $(0.04)^{* *}$ & $\begin{array}{l}-0.04 \\
{[1.00]}\end{array}$ & $(0.03)^{* *}$ \\
\hline$D_{D e L i}$ & $\begin{array}{l}-0.66 \\
{[0.24]^{* * *}}\end{array}$ & $(0.01)^{* *}$ & $\begin{array}{l}-0.59 \\
{[0.39]}\end{array}$ & $(0.52)$ & $\begin{array}{l}-1.71 \\
{[0.71]^{* *}}\end{array}$ & $(0.67)$ & $\begin{array}{l}-0.32 \\
{[1.02]}\end{array}$ & $(0.11)$ \\
\hline$D_{D e D e}$ & $\begin{array}{l}-1.36 \\
{[0.36]^{* * *}}\end{array}$ & (10 & $\begin{array}{l}-0.74 \\
{[0.38]^{*}}\end{array}$ & & $\begin{array}{l}-1.86 \\
{[0.71]^{* * *}}\end{array}$ & & $\begin{array}{l}-1.32 \\
{[1.10]}\end{array}$ & \\
\hline Panel b & & & & & & & & \\
\hline Alliance & $\begin{array}{l}-0.72 \\
{[0.21]^{* * *}}\end{array}$ & & $\begin{array}{l}-0.10 \\
{[0.18]}\end{array}$ & & $\begin{array}{l}-0.19 \\
{[0.28]}\end{array}$ & & $\begin{array}{l}-1.10 \\
{[0.49]^{*}}\end{array}$ & \\
\hline MajPower & $\begin{array}{l}0.02 \\
{[0.26]}\end{array}$ & & $\begin{array}{l}0.35 \\
{[0.54]}\end{array}$ & & $\begin{array}{l}0.64 \\
{[0.88]}\end{array}$ & & $\begin{array}{l}-0.68 \\
{[1.47]}\end{array}$ & \\
\hline LogCapRatio & $\begin{array}{l}-0.10 \\
{[0.11]} \\
\end{array}$ & & $\begin{array}{l}-0.10 \\
{[0.14]}\end{array}$ & & $\begin{array}{l}-0.19 \\
{[0.36]}\end{array}$ & & $\begin{array}{l}-0.25 \\
{[0.36]}\end{array}$ & \\
\hline Model & $\mathrm{CL}$ & DGIT & & LOGIT & CLC & GIT & & GIT \\
\hline Years & 181 & -1945 & & $46-2000$ & 1984 & 2000 & 198 & -2000 \\
\hline Observations & & 143 & & 15615 & & & & 24 \\
\hline (pseudo) R2 & & .13 & & 0.05 & & & & 14 \\
\hline
\end{tabular}

Notes: ${ }^{*}$ significant at $10 \%$; $* *$ significant at $5 \%$; *** significant at $1 \%$. Robust standard errors reported in brackets below each coefficient. P-values for a Wald test of equality between each coefficient and the coefficient of $D_{D e D e}$ is reported in parenthesis next to the corresponding standard error. All parameters are estimated using conditional logit models with fixed effects at the dyadic level. Each regression model includes (coefficient not reported) year fixed effects and cubic spline terms in the number of years since a country pair is last involved in a MID (see footnote 17 for additional detail.) The regression models are analogous to Model 1 of Table 6 but the parameters are estimated on the sub-samples reported at the bottom of each column. 
Figure 1: Hawkish Limited Democracies

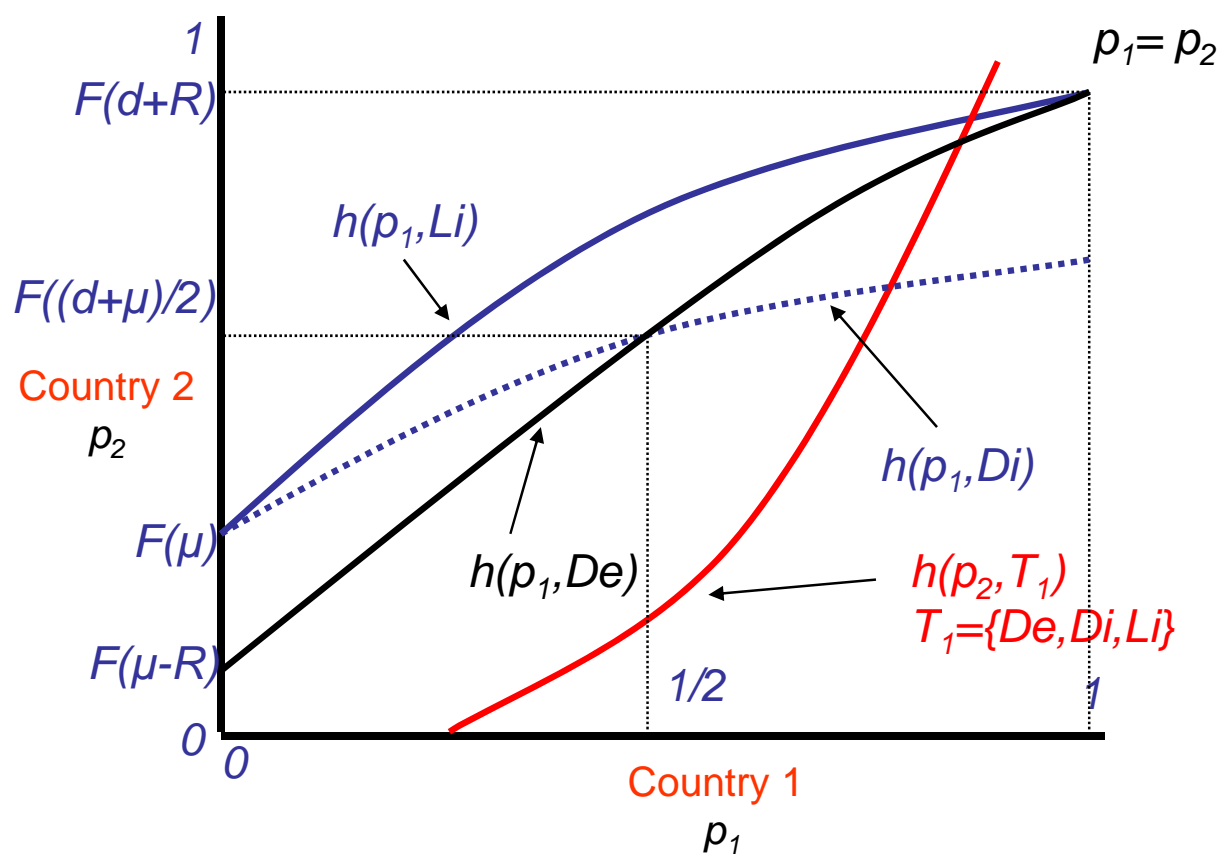


Figure 2: Dyadic Democratic Peace

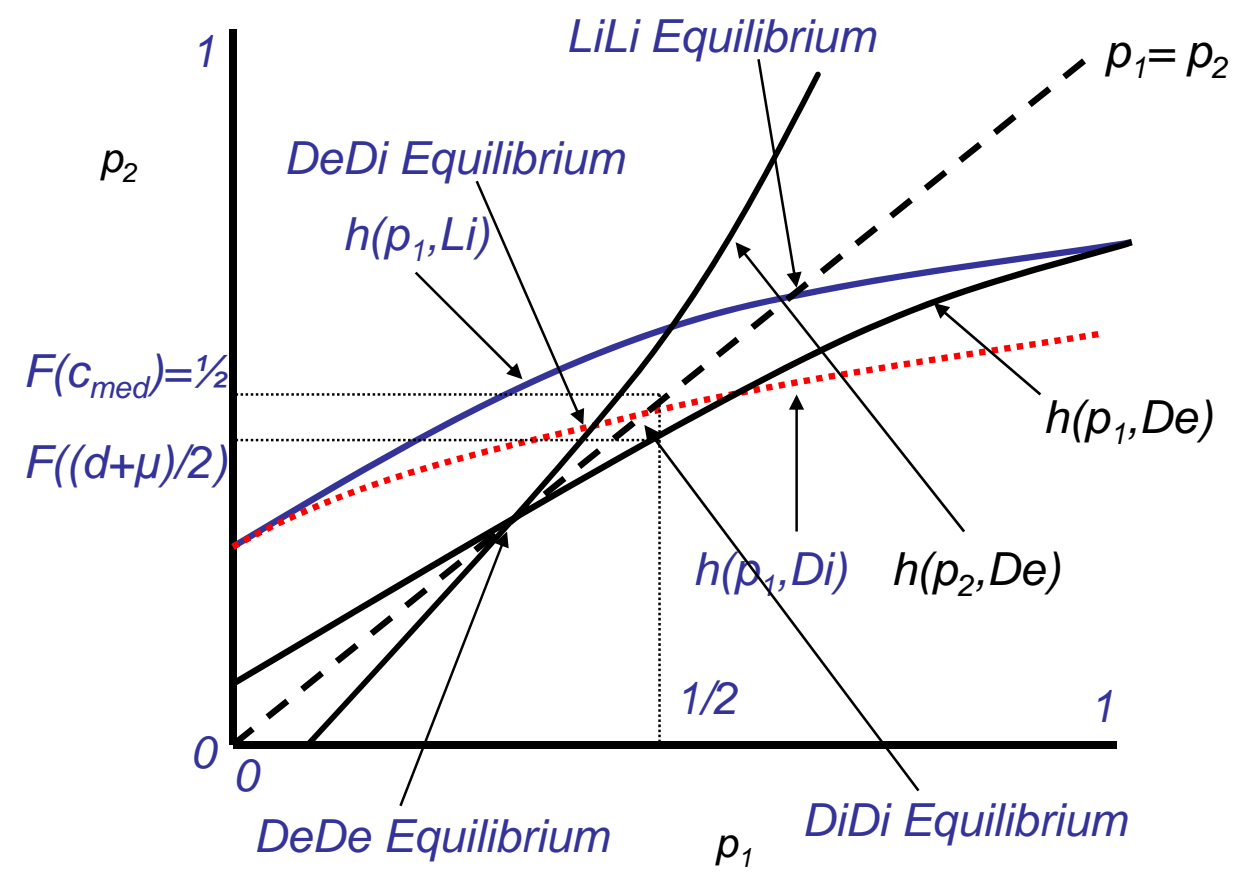




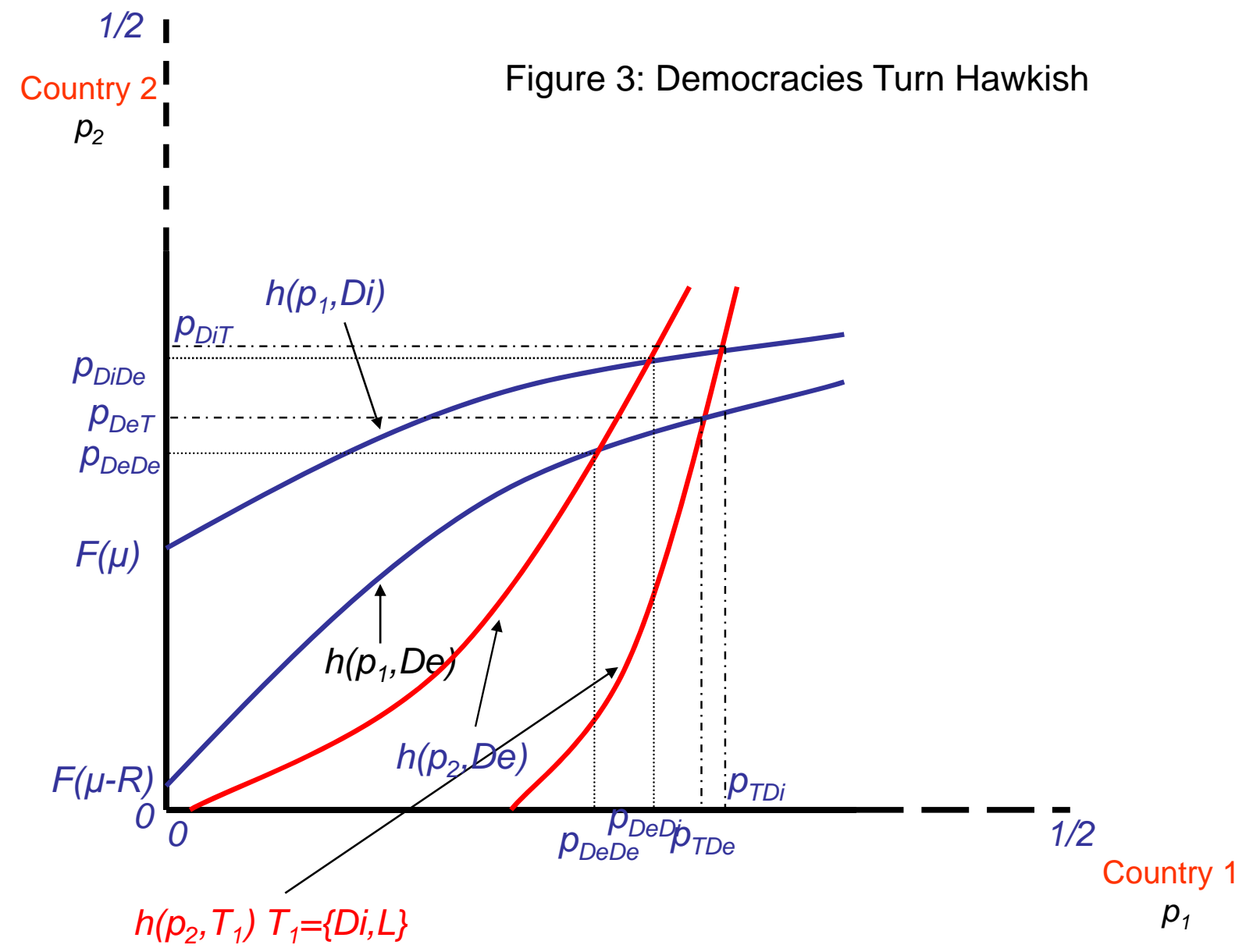

